\title{
CITIZEN ENVIRONMENTAL LITIGATION AND THE ADMINISTRATIVE PROCESS: EMPIRICAL FINDINGS, REMAINING ISSUES AND A DIRECTION FOR FUTURE RESEARCH
}

\author{
Joseph F. DiMento*
}

During the last decade, considerable legislative activity has centered around determining the proper roles of citizens in administrative decisionmaking. ${ }^{1}$ The public bureaucracy is not a new setting for active participation of private citizens. ${ }^{2}$ However, citizen involvement has recently taken on a new thrust. Especially in the area of decisions related to environmental

* A.B. 1969, Harvard College; Ph.D. and J.D. 1974, University of Michigan. Assistant Professor of Social Ecology, University of California, Irvine. Member of the California Bar. The author is indebted to Ms. Colleen Wilks for research assistance on this Article and to Ms. Juanita Melgoza for assistance in preparation of the manuscript.

THE FOLLOWING CITATION WILL BE USED IN THIS ARTICLE:

DiMento, Citizen Environmental Legislation in the States: An Overview, 53 J. URB. L. 413 (1976) [hereinafter cited as DiMento, Overview].

1. For example, numerous states and the federal government have considered passage of some version of the Model Natural Resources and Environmental Protection Act. See Sax \& DiMento Environmental Citizen Suits: Three Years' Experience Under the Michigan Environmental Protection Act , 4 EcoLoGY L.Q. 1, 3 n.6 (1974) (recent compilation of states which have considered bills based on the Model Act). DiMento, Overview 457 summarizes the legislation in states which have passed a version of the Model Act. For a sample of other types of citizen suit legislation currently found in the states, see Figure 1 infra.

On the federal level, private citizens have been given powers to bring suit against the administrators of several government agencies for failure to carry out certain statutory mandates. E.g., Federal Water Pollution Control Act Amendments of 1972, 33 U.S.C. $\S 1365$ (Supp. V. 1975); Clean Air Act Amendments of 1970, 42 U.S.C. \$ 1857h-2 (1970); National Environmental Policy Act of 1969, 42 U.S.C. \$\$ 4331-4335 (1970).

2. The literature on citizen participation in administrative agency activities is immense. See, e.g., J Goodman \& E. Hanson, an Evaluation of Policy Related Research on Citizen Participation in Municipal Service Systems: Environmental Planning (1974) (NSF-RA-S-74-044H, Citizen Participation in Municipal Service Systems Analysis Project, Monograph Number 8, prepared by Program in Health Planning, School of Public Health, University of Michigan and the Technical Assistance Research Program Institute); D.HOEH, Participation and the Proposed A.L.I. Model Land Development Code (1975) (presented at the 57th Annual Conference of the American Institute of Planners); A. Scoville, Citizen Participation in State Government, A Summary RePort (1973) (prepared for the Office of Exploratory Research and Problem Assessment, NSF-RANN, by the Citizen Participation Project, The Environmental Planning Information Center, Montpelier, Vermont, Grant No. GI-33647). See also Cramton, The Why, Where and How of Broadened Public Participation in the Administrative Process, 60 GEO. L.J. 52.5 (1972); Emond, Participation and the Environment: A Strategy for Democratizing Canada's Environmental Protection Laws, 13 OsGoodE HALL L.J. 783 (1975); Forkosch, Administrative Conduct in Environmental Areas-A Suggested Degree of Public Control, 12 S. TEx. L.J. 1 (1970); Hanes, Citizen Participation and 
quality, members of the public have lobbied for, and in many states have been granted, participation in the decision-making process which is much more direct and immediate than that which has been available through traditional means. Unsatisfied with the results obtained through service on advisory boards and commissions or by providing comments and opinions in public hearings or rule-making proceedings, citizens have sought to have their analyses and opinions injected into the public domain with the force of law. Perhaps most significantly, they have urged their legislatures to grant them the power to initiate law suits to present and vindicate their positions in environmental management controversies. Private parties have attempted to remove obstacles to judicial review of administrative actions and decisions and to create new causes of action against legal entities in both the public and private sectors.

Generally, citizens have sought to be permitted to initiate environmental lawsuits in two types of situations: they have demanded authority to bring suits to challenge government efforts or failures to manage or regulate the environment, and they have pressed for the right to sue other private entities to enjoin the latter's activities on public or private lands which violate specific statutory standards.

FIGURE 1

\section{A Continuum of Citizen Suit Legislation with Some State Examples}

$\begin{array}{lll}\text { General en- } & \text { Litigation al- } & \text { Litigation al- } \\ \text { vironmental } & \text { lowed upon } & \text { lowed in } \\ \text { cause of action } & \text { specified act or } & \text { specified geo- } \\ \text { and broad pro- } & \text { omission by } & \text { graphic re- } \\ \text { cedural rights. } & \text { government ad- } & \text { gions-"critical } \\ & \begin{array}{l}\text { ministrators or } \\ \text { private parties. }\end{array} & \text { area legisla- } \\ & \text { tion." }\end{array}$

Litigation al- Litigation allowed upon lowed in specified act or specified reomission by gions upon act government ad- or omission by ministrators in government adspecified sub- ministrators. stantive regulatory arenas.

\begin{tabular}{|c|c|c|c|c|}
\hline $\begin{array}{l}\text { Michigan En- } \\
\text { vironmental } \\
\text { Protection Act, } \\
\text { MICH. CoMP. } \\
\text { LAWS ANN. } \$ \S \\
691.1201- \\
.1207 \text { (Supp. }\end{array}$ & $\begin{array}{l}\text { New Jersey } \\
\text { Zoning Law,* } \\
\text { N.J. STAT. ANN. } \\
\text { § 40:55 D-4 } \\
\text { (West Supp. } \\
\text { 1976) }\end{array}$ & $\begin{array}{l}\text { Colo. Recrea- } \\
\text { tion Land Pres- } \\
\text { ervation Act, } \\
\text { CoLo. REV. } \\
\text { STAT. \$§ 25-13- } \\
101 \text { to }-114 \\
\text { (1974) }\end{array}$ & $\begin{array}{l}\text { Mississippi Air } \\
\text { and Water Pol- } \\
\text { lution Control } \\
\text { Act of } 1966 \text {, } \\
\text { MISS. CODE } \\
\text { ANN. § 49-17-1 } \\
\text { to }-43(1972)\end{array}$ & $\begin{array}{l}\text { California con- } \\
\text { sistency } \\
\text { requirement,* } \\
\text { CAL. Gov'T } \\
\text { CODE § } 65860 \\
\text { (West Supp. } \\
\text { 1977) }\end{array}$ \\
\hline 1975) & & $\begin{array}{l}\text { Cal. Coastal } \\
\text { Zone Initiative, } \\
\text { CAL. PUB. RES. } \\
\text { CoDE } § 30801 \\
\text { (West Supp. } \\
\text { 1977) }\end{array}$ & & \\
\hline
\end{tabular}

\footnotetext{
* Indicates that the class of plaintiffs is circumscribed, such as by geographic location (resident of city or county) or status (landowner).
} 
The states have varied in their responses to these demands and, consequently, in the legal status they accord to citizen-initiated legislation. As Figure 1 suggests, ${ }^{3}$ several approaches are identifiable. In the most responsive states (Michigan being the leader), citizens may bring suit to challenge a wide range of public and private activities which are likely to affect the state's natural resources. ${ }^{4} \mathrm{~A}$ second group of states provides a more limited right of private suit to protect specific ecologically valuable areas of the state. ${ }^{5}$ The most limited kind of citizen suit provision empowers individuals to go to court to ensure the propriety of certain administrative actions. ${ }^{6}$

Its Impact Upon Prompt and Responsible Administrative Action, 24 Sw. L.J. 731 (1970); Krier, Environmental Watchdogs: Some Lessons from a "Study" Council, 23 STAN. L. REv. 623 (1971); Large, Is Anybody Listening? The Problem of Access in Environmental Litigation, 1972 WIS. L. Rev. 62; Lenny, The Case for Funding Citizen Participation in the Administrative Process, 28 AD. L. REv. 483 (1976); Lucas, Legal Foundations for Public Participation in Environmental Decision Making, 16 NAT. RESOURCES J. 73 (1976); Miller, Ecology and the Administrative Process, 23 AD. L. REv. 59 (1970); Wandesforde-Smith, The Bureaucratic Response to Environmental Politics, 11 NAT. RESOURCES J. 479 (1971); Wengert, Citizen Participation: Practice in Search of a Theory, 16 NAT. RESOURCES J. 23 (1976).

3. The continuum is not claimed to be exhaustive of the range of legislative options in providing for citizen environmental suits. Rather, it is presented as a heuristic and will be modified upon completion of the research described in text accompanying notes 164-71 infra.

4. Environmental citizen suits gained much of their impetus from Michigan's passage of its Environmental Protection Act in 1970. See Mich. CoMp. LaWs ANN. \$\$ 691.1201-.1207 (Supp. 1976). See also Sax \& DiMento, supra note 1, at 1-3. Since then, at least eight other states have followed Michigan's lead and enacted versions of the Model Natural Resources and Environmental Protection Act-the Sax Act, as it is commonly referred to in honor of its author. See Conn. Gen. Stat. Ann. §§ 22a-14 to 20 (West Supp. 1977); Fla. Stat. AnN. § 403.412 (West 1973); IND. CODE ANN. \$\$ 13-6-1-1 to-6 (Burns 1973); MASS. ANN. LAWS. ch. 30, \$§ 61, 62, ch. 214, § 10A (Michie/Law. Co-op 1973 \& Supp. 1977); MinN. STat. ANN, §§ 116B.01.13 (WWest Supp. 1977); Nev. Rev. Stat. \$§ 41.540-.570 (1973); N.J. Stat. ANN. §§ 2A:35A-1 to-14 (West Supp. 1976); S.D. CompIL ED LAws ANN. \$§ 21-10A-1 to-15 (Supp. 1976). California has also enacted a version of the Sax Act. CAL. Gov'T CODE $\$ \$ 12600-12612$ (West Supp. 1977). However, that Act does not confer standing on private individuals. California citizens wishing to bring suits for environmental protection must act through the state attorney general. See id. $\S$ 12607; DiMento, Overview 415 n.6. A comparative table demonstrating the differences among state acts can be found in DiMento, Overview 457 apps. B,C.

A recent listing of other states whose legislatures are currently considering versions of the Model Natural Resources and Environmental Protection Act is found in Sax \& DiMento, supra note 1, at 3 n.6. A bill has recently been introduced in Missouri which generally follows the Model Act but provides for the initial attempt at resolution of environmental controversies to be made by administrative agencies through standard regulatory channels. Mo. H.B. 623 (1977) (introduced by Rep. Carl Muckler). Maine also has a version of the Sax Act under consideration. Me. Leg. Doc. 646 (1977) (introduced by Rep. William Blodgett).

There has also been some consideration of the Sax Act on the federal level. See S. 1104, 93d Cong., Ist Sess. (1973); Hearings on S. 1104 Before the Subcomm. on the Environment of the Senate Subcomm. on Commerce, 93d Cong., 1st Sess. (1973). See also H.R. 779, 94th Cong., lst Sess. (1975) (providing for environmental class actions).

5. Colorado, for example, allows citizens to initiate lawsuits where they have observed abuses of recreational lands. See CoLo. Rev. STAT. § 25-13-112 (1974).

6. See, e.g. , CAL. Gov'T CODE $\S 65860$ (West Supp. 1977). Under California's "consistency requirement," see id. $\S 65860$ (a), any "resident or property owner within a city or a county 
In many jurisdictions, environmental litigation by private citizens is restricted to a strictly limited set of circumstances. Private parties are frequently precluded from acting until specified land uses are proposed or have begun, ${ }^{7}$ identified government officials have taken particular actions or have failed to act as legally required, ${ }^{8}$ or prerequisites such as exhaustion of administrative remedies have been met by the prospective citizen litigant. ${ }^{9}$

A variety of substantive and procedural reforms have been developed to circumvent these restrictive requirements. In some states, for example, standing to sue has been liberalized so that environmental plaintiffs may invoke the power of the courts without demonstrating the kind of actual injury which is normally a prerequisite to seeking judicial relief. ${ }^{10}$ Other

.. . may bring an action" to challenge zoning ordinances which are inconsistent with the general plan. Id. $\$ 65860(\mathrm{~b})$.

7. See, e.g., id.

8. See, e.g., Fla. Stat. ANN. § 403.412(2) (a) (West 1973); N.J. Stat. Ann. § 40:55D-17 (West Supp. 1976).

9. E.g., Fla. Stat. ANN. § 403.412(2) (b) (West 1973); Ind. Code ANN. § 13-6-1-I(b) (Burns 1973).

10. State standing doctrines often require an individual to be affected or harmed in a direct and particular manner as a prerequisite to having a court hear his case. See generally Davis, The Liberalized Law of Standing, 37 U. CHs. L. REv. 450, 468-69 (1970). For examples of states which have liberalized their standing requirements to eliminate the requirement of actual injury when private parties seek to redress harms to the environment, see CONN. GEN. STAT. ANN. \& 22a-16 (West Supp. 1976); IND. CODE ANN. § 13-6-1-1(a) (Burns 1973); MICH. CoMP. LAwS ANN \& 691.1202(1) (Supp. 1976); MiNN. STAT. ANN. §116B.03(1) (West Supp. 1977).

Analyses of the standing doctrine generally and of the special problems of standing for environmental plaintiffs have been voluminous. See Albert, Standing to Challenge Administrative Action: An Inadequate Surrogate for Claim for Relief, 83 YALE L.J. 425 (1974); Allen, The Problem of Standing to Sue and Public Involvement in Federal Resource Management, 7 NAT. RESOURCES LAW. 87 (1974); Cramton \& Boyer, Citizen Suits in the Environmental Field-Peril or Promise?, 2 EcologY L.Q. 407 (1972); Eckhardt, Citizens Groups and Standing, 51 N.D.L. REv. 359 (1974); Hughes, Who's standing? Problems with Inanimate Plaintiffs, 4 ENVT'L L. 315 (1974); Large, supra note 2; McLennan, State Legislation to Grant Standing: Questions, Answers and Alternatives, 2 ENvT'L L. 313 (1972); Rogers, The Alice-In-Wonderland World of Standing, 1 ENVT'L L. 169 (1971); Stone, Should Trees Have Standing? Toward Legal Rights for Natural Objects, 45 S. CAL. L. REv. 450 (1972); Tremaine, Standing in the Federal Courts for Conservation Groups, 6 URBAN LAW. 116 (1974); Note, Citizen Organizations Intervening in Federal Administrative Proceedings: The Lingering Issue of Standing, 51 B.U. L. REv. 403 (1971); Comment, Standing in Environmental Litigation: Let's Get to the Merits, 10 CAL. W.L. REv. 182 (1973); Comment, Constitutional Challenge to the Price-Anderson Act: Ripeness and Standing Before the Holocaust, 1976 DUKE L.J. 967; Comment, Standing on the Side of the Environment: A Statutory Prescription for Citizen Participation, 1 ECOLoGY L.Q. 561 (1971); Comment, Standing and Administrative Agencies-Expanding Concepts of Judicial Review, 32 LA. L. REv. 634 (1972); Note, Standing: Who Speaks for the Environment?, 32 MONT. L. REv. 130 (1971); Comment, The Role of the Judiciary in the Confrontation with the Problems of Environmental Quality, 17 U.C.L.A. L. REV. 1070 (1970); Note, Standing to Sue Under the Model Land Development Code, 9 U. MrCH. J.L. REF. 649 (1976); Note, Environmental Protection: A Limited Expansion of the Citizen's Role, 12 WASHBURN L.J. 54 (1972). It is not the purpose of this Article to present any new analysis of standing or its reforms, but only to discuss some remaining conceptual difficulties with expanded standing for environmental plaintiffs. See text accompanying notes 77-95 infra. 
states have legislated substantive legal rights or general standards of environmental protection which citizens are empowered to enforce through the courts. ${ }^{11}$ Under such provisions, the courts may measure the legality of an action of a public- or private-sector defendant against a standard that has not been operationalized in any specified state law or administrative regulation. ${ }^{12} \mathrm{~A}$ number of states have focused their reform efforts on enlarging the scope of judicial review of administrative actions. Some jurisdictions have provided for expansive judicial scrutiny through citizen-initiated suits, in response to which courts are authorized to substitute their views for those of administrative agencies. ${ }^{13}$

With these procedural and substantive innovations, the potential for citizen involvement in the processes of environmental regulation and control is considerable. But a wide range of opinion exists as to the desirability of admitting the individual citizen to a more active role in the resolution of environmental controversies. Perceived effects of citizen suits are classified and weighted differently by lawyers, environmental and administrative law professors, and the state and local government administrators and judges who adjudicate citizen-initiated controversies. These perceived effects have been summarized, clustered and presented in Tables 1 and 2 .

It is not the purpose of this work to explicate the various arguments for or against citizen suits. These arguments have been presented in detail elsewhere. ${ }^{14}$ Rather, this Article will explore some of the remaining issues which face those who must consider the use of citizen litigation as a vehicle for involving the public in the policy-making process. Such factors as administrative efficiency, democratic participation and the difficult-todescribe but critically important need to arrive at a concept of the public interest, must all be examined.

In order to pursue this task, the remainder of this Article is divided into three parts. The first section presents some of the empirical work completed on citizen environmental litigation and its impact on administrative functioning, including the administration of the judiciary. Particular emphasis is given to those studies which may be useful in assessing the validity of the arguments for and against citizen suits which have been set forth in Tables 1

11. See, e.g., Conn. Gen. Star. AnN. \$§ 22a-14 to -20 (West 1975); Minn. Star. AnN. §§ 116B.01-.13 (West Supp. 1976).

12. Consider, for example, the Model Act as it has been adopted in Michigan. The statute grants a broad right of action to any legal entity "for the protection of the air, water and other natural resources and the public trust therein from pollution, impairment or destruction." Mich. Comp. Laws ANn. § 691.1202(1) (Supp. 1976); accord, Conn. Gen. STat. ANN. § 22a-16 (West 1975); Minn. Stat. ANN. \& 116 b.0 (West 1977).

13. These statutes may allow for de novo review of agency actions. See, e.g., CONN. GEN. STaT. ANN. § 22a-18(c) (West 1975); Mich. Comp. Laws ANN. § 691.1202(2) (Supp. 1976); Nev. REv. STAT. $\$$ 41.540-.570 (1973).

14. ' See DiMento, Overview 418-27. 


\section{TABLE 1}

Propositions from the Legal Literature in Support of Environmental Citizen Suit Provisions

1. Administrative agencies become inordinately responsive over time to the special interests in society that they are created to regulate or assist. Rather than working for the public interest, the daily operations of administrative agencies promote private vested interests and discourage citizen participation. Citizen environmental suits make visible the "insider perspective" which dominates decision-making in the agencies. Citizen suits thus: first, expose questionable decision-making approaches in defendant agencies to public view, and second, subject agencies in general to the scrutinizing overview of interested private citizens. In short, citizen environmental suits serve functions analogous to special and general deterrence. ${ }^{\mathrm{a}}$

2. Some decision-making on environmental matters should be shifted to the courts, for the judiciary is well equipped to analyze value-laden environmental problems objectively and to engage in the delicate balancing processes required to reach sound decisions in a pluralistic society. ${ }^{b}$

3. Existing state and local administrative structures cannot respond adequately to complex environmental controversies. These controversies and decisions are not readily amenable to solutions in single-purpose government agencies or in understaffed, jurisdictionally irrational and non-representative local governments. Citizen environmental suits force complex decisions into the better-equipped judicial setting.c

4. Environmental decisions of ten take far too long to emerge from the present decision structure. Unlike the administrative process, the judicial process is inexorable: once the process is begun through the filing of a complaint, subsequent action is inevitable-if not always rapid. No gaps are left which a discretionary determination by an administrator can turn into a termination of the decision-making process and a decision by default. ${ }^{d}$

5. Traditional law on judicial review places the citizen concerned with environmental management in a highly disadvantageous position vis-a-vis administrative agencies. In order to effectuate the shift of some environmental decision-making to the courts, expanded judicial review of administrative agency decisions should be permitted. This is necessary because under the substantial evidence-rational basis rule, environmentalists are faced with onerous burdens. ${ }^{e}$

6. Citizen environmental litigation actively involves citizens in the process of environmental management; it promotes citizen satisfaction with decisions reached by government. ${ }^{f}$

a. See J. SAX, Defending the ENVIRONMENT 56-57 (1971); Lenny, The Case for Funding Citizen Participation in the Administrative Process, 28 AD L. REV. 483, 490-94 (1976); Murphy \& Hoffman, Current Models for Improving Public Representation in the Administrative Process, 28 AD. L. REV. 391, 392-96 (1976); Sax, The Public Trust Doctrine in Natural Resource Law: Effective Judicial Intervention, 68 MICH. L. REV. 471, 495-96 (1970); Comment, Standing in Environmental Litigation: Let's Get to the Merits, 10 CAL. W.L. REv. 182, 183-84 (1973), Comment, Standing on the Side of the Environment: A Statutory Prescription for Citizen Participation, 1 EcoloGY L.Q. 561, 567-74 (1971); Comment, Environmental Protection: Citizen Action Forcing Agency Compliance Under Limited Judicial Rewiew, 6 ST. MARY's L.J. 421, 433-36, 440 (1974); Comment, The Roie of the Judiciary in the Confrontation with Problems of Environmentai Quality, 17 U.C.L.A. L. REV. 1070, 1098-99 (1970).

b. See J. SAX, supra note a at 149-57; Sive, Some Thoughts of an Environmentai Lawyer in the Wilderness of Administrative Law, 70 CoLUM. L. REv. 612, 629-31 (1970); Sive, The Role of Litigation in Environmental Policy: The Power Plant Siting Probiem, 11 NAT. Resources J. 467, 470-71 (1971); Smith, The 


\section{TABLE 2}

\section{Propositions from the Literature in Opposition to Environmental Citizen Suit Provisions}

1. Lawsuits engender great delays in environmental and land use decisions, which can be more expeditiously made by competent local officials. ${ }^{8}$

2. The introduction of the citizen suit results in clogging of court calendars. Great volumes of environmental litigation force courts to adjudicate in areas where they are least competent, or at least in areas of secondary importance when compared with those with which courts are more traditionally involved. ${ }^{\text {h }}$

3. The court is not a good forum for the resolution of "polycentric" problems. These involve "a complex of decisions, judgment upon each of which depends upon the judgment to be made upon each of the others." Court procedures, including those of pleading, evidence evaluation and remedy choice are not compatible with the flexibility needed for response to complex, multifaceted problems. In addition, proper environmental decision-making is highly political in nature; moving political questions to the judiciary casts doubt on the decisions made and the courts themselves. ${ }^{i}$

4. Rather than adding another factor into a management process in need of new perspectives, citizen suits provide the means by which litigious individuals can harass government agencies and promoters of unpopular land uses. These abuses result in-among other outcomes-movement of industry from those jurisdictions which grant citizens litigation power. Adverse statewide economic consequences follow. ${ }^{\mathrm{j}}$

5. The judiciary, to which environmental decisions are shifted by citizen suits, is not as accountable to the public as legislatures and administrative agencies. Administrative agencies and local government are amenable to lobbying and other legitimate means of allowing the participation of many groups interested in the complicated decisions of environmental planning. ${ }^{k}$

6. Citizen-initiated lawsuits impede rational long-range planning, policy formulation and regulation. Regardless of motivation, non-experts lack skills needed to address the questions which guide natural resource allocation. Litigation based on narrow understandings of societal needs, far from fostering improvements in a generally workable planning process, tends to divert the attention of administrators to individual controversies; balkanization of regulatory law may ensue. ${ }^{1}$

7. Citizen suit statutes impose extremely vague standards for environmental control and therefore force the judiciary to make decisions which are technically difficult or constitutionally suspect. Existing standards for judicial review provide sufficient judicial intervention into administrative environmental decision-making. De novo review would result in misuse of governmental resources. ${ }^{\mathrm{m}}$

8. Citizen environmental suits are excessively expensive, both for government agencies and for private litigants. ${ }^{n}$

Environment and the Judiciary: A Need for Cooperation or Reform?, 3 ENVT'L AFF. 627, 639 (1974); Comment, Standing on the Side of the Environment: A Statutory Prescription for Citizen Participation, supra note a, at $640-41$.

c. See J. SAX, supra note a, at 58-62; Forkosch, Administrative Conduct in Environmental Areas-A Suggested Degree of Public Control, 12 S. TEx. L.J. 1, 2-7 (1970); Murphy \& Hoffman, supra note a, at 393-96.

d. See J. SAX, supra note a, at 116-24; Comment, Standing on the Side of the Environment: A Statutory Prescription for Citizen Participation, supra note a, at 576 n.57; P. Schroth \& Z. Plater, Environmental Law: 
and 2. Section two attempts to frame some of the questions which remain unanswered by currently available empirical and conceptual work. In section three, some research directions for the future-issues for both legal research and scientific fieldwork-are suggested. Each of the questions posed by this last section is regularly confronted by the practicing attorney, the citizen litigant and the administrative agency.

Before beginning, it must be emphasized that while the focus of this analysis is on citizen involvement in environmental policy-making, the concepts and data presented are not necessarily limited in applicability to that area. Environmental policy has been selected on the basis of current interest and rapid development. But the general issues discussed and the conceptual framework developed should be equally applicable in considering methods for involving the public in other spheres of policy.

\section{CITIZEN SUITS: SOME EMPIRICAL CONSIDERATIONS}

Few systematic studies have investigated the impact of citizen involvement on public actions. In general, the literature on public participation in government decision-making "has tended to be prescriptive and hortatory, abounding with rhetoric and polemics and resting on unanalyzed premises and assumptions." 15 The literature on the effects of citizen litigation has been no exception. There have been few systematic studies and much of the analysis that has been undertaken has been unsupported by empirical fact. Fortunately, there are several studies which allow some preliminary assess-

15. Wengert, supra note 2 , at 24 .

An Introduction to the American Legal System (1973) (unpublished fifth preliminary edition of textbook used at Universities of Michigan, Tennessee and California, Oberlin College and Southern Methodist University).

e. See Sive, Some Thoughts of an Environmental Lawyer in the Wilderness of Administrative Law, supra note $b$, at 619 . Several of these arguments have been made in analyses of proposed federal provisions, but they are, for the most part, equally applicable to reforms in the states.

f. See Sax \& Conner, Michigan's Environmental Protection Act of 1970: A Progress Report, 70 Micll. L. REV. 1103, 1080-81 (1972).

g. See Cramton, Citizen Suits in the Environmental Field-Peril or Promise?, 25 AD. L. REv. 147, 153-55 (1973); Leventhal, Environmental Decision-making and the Role of the courts, 122 U. PA. L. REV. 509, 518-19 (1974).

h. See Cramton, supra note g, at 151; Cramton \& Boyer, Citizen Suits in the Environmental Field: Peril or Promise?, 2'ECOLOGY L.Q. 407, 412 (1972).

i. See Cramton, supra note g, at 151-52; Cramton \& Boyer, supra note h, at 412; Leventhal, supra note $\mathrm{g}$, at $545-50$.

j. See Cramton, supra note $\mathrm{g}$, at 150 .

k. See Cramton, supra note g, at 151-52; Hanes, Citizen Participation and Its Impact upon Prompt and Responsible Administrative Action, 24 Sw. L.J. 731, 736 (1970).

1. See Cramton, supra note g, at 153-55; Cramton \& Boyer, supra note h, at 416-17; Hanes, supra note k, at 738-39; Jaffe, Ecological Goals and the Ways and Means of Achieving Them, 75 W. VA. L. REv. 1, 23-24 (1972).

m. See Cramton, supra note g, at 154-55; Cramton \& Boyer, supra note h, at 419-22; Jaffe, The Administrative Agency and Environmental Control, 20 BUFFALO L. REV. 231, 234-35 (1970); Hearings on the Environmental Protection Act of 1973 (S. 1104) Before the Subcomm. on the Environment of the Senate Comm. on Commerce, 93d Cong., lst Sess. 51 (1973).

n. See Cramton \& Boyer, supra note h, at 417-19. 
ments of the arguments advanced for and against citizen suit legislation. The results of some of these are outlined below.

\section{A. Influence of Special Interests}

Reports on the federal system have documented considerable movement in and out of federal regulatory agency staffs by industry representatives and overrepresentation of certain private interest groups on federal advisory committees. ${ }^{16}$ These reports provide circumstantial support for the now-familiar proposition that many regulatory agencies are inordinately responsive to the special interests in society which they are created to regulate. ${ }^{17}$ To the extent that agency decision-making is dominated by vested interests, the argument for citizen suits is clear. Such suits may expose questionable decision-making approaches in government agencies to public view and subject agencies to public oversight through the courts. ${ }^{18}$

\section{B. Judicial Competence in Complex Issues}

The question of whether the courts are the proper forum for resolution of complex, value-laden issues, such as those found in environmental management, is critical to determining whether the citizen suit is actually a desirable vehicle for keeping agencies responsive to the public. ${ }^{19}$ The history of litigation under the Michigan Environmental Protection Act (ME$\mathrm{PA})^{20}$ is instructive. An early study reported that the judiciary was responding capably to the complex environmental matters presented in suits brought under MEPA in its first three years. ${ }^{21}$ Judges were perceived by both

16. See, e.g. Sierra Club v. Morton, 405 U.S. 727, 746, 748 n.7 (1972) (Douglas, J., dissenting); Hearings on S.3067 Before the Subcomm. on Intergovernmental Relations of the Senate Comm. on Government Operations, 91 st Cong., 2d Sess. 15-27, $49-70$ (1970) (testimony of W. Rogers \& T. Kimball). For a discussioin of the ethical problems posed by this movement, see Note, Ethical Problems for the Law Firm of a Former Government Attorney: Firm or Individual Disqualification?, 1977 DUKE L.J. 512.

17. See, e.g. , G. McConnell, Private Power and American Democracy (1967).

18. See generally J. SAX, DEFENDING THE ENVIRONMENT (1971); DiMento, Overview 419-20; Lenny, supra note 2; Murphy \& Hoffman, Current Models for Improving Public Representation in the Administrative Process, 28 AD. L. Rev. 391 (1976); Sax, The Public Trust Doctrine in Natural Resources Law: Effective Judicial Intervention, 68 MICH. L. REV. 471 (1970); Comment, Environmental Protection: Citizen Action Forcing Agency Compliance Under Limited Judicial Review, 6 ST. MARY's L.J. 421 (1974).

19. Compare note $b$ in Table $l$ and accompanying text with note $i$ in Table 2 and accompanying text. For the contrasting views of two able federal judges on the desirability and soundness of judicial review in cases involving complex scientific and technical issues, compare the majority opinion of Judge Leventhal with the concurring opinion of Chief Judge Bazelon in Internatonal Harvester Co. v. Ruckelshaus, 478 F.2d 615 (D.C. Cir. 1973). See also, comments by Judge James L. Oakes of the Court of Appeals for the Second Circuit before a conference of the ALI-ABA-ELI, Smithsonian Institution, Washington D.C. (February 11, 1977).

20. Mich. COMP. LAwS ANN. §§ 691.1201-.1207 (Supp. 1976).

21. See Sax \& DiMento, supra note 1, at 52. 

cause of the lack of any comparable data on resolution rates in administrative agencies. ${ }^{27}$

Those who oppose citizen environmental suit legislation assert that lawsuits will cause great delays in the agency decisional process ${ }^{28}$ and will needlessly burden already crowded court dockets. ${ }^{29}$ Little information is currently available at the state level which can be used to assess the impact of citizen suits on the administration of justice. The Michigan study has found that the mean duration of MEPA cases is eleven months in the trial courts. ${ }^{30}$ When appeals are included, this average increases to almost one year. ${ }^{31}$

The federal level provides another relevant set of statistics. ${ }^{32}$ In a recent report on the feasibility of establishing a federal environmental court ${ }^{33}$ the General Services Administration indicated that while less than $2 \%$ of the cases awaiting adjudication by GSA involved significant environmental issues, "[t]hese seven cases [representing the $2 \%$ figure] are among the most significant cases involving this agency and are most time-consuming and complex." 34 While the report did not specify how many of these actions were citizen-initated, ${ }^{35}$ the GSA's experience does reflect the burden which environmental cases can impose on government resources.

Calendar impact is a function of volume as well as duration of citizen environmental suits. Some studies have attempted to measure the volume of environmental suits, but few generate high levels of confidence in the results because of the absence of scientific design in investigation. The Attorney General's report indicated that less than seven-tenths of one percent $(0.7 \%)$

27. Data on the parallel activity in administrative agencies have not been assembled, to the author's knowledge, except in anecdotal fashion. See P. Schroth \& Z. Plater, supra note 25, at 17.26-.28, for some interesting examples of administrative agency "inaction" in the environmental field.

28. See, e.g., Cramton, Citizen Suits in the Environmental Field-Peril or Promise?, 25 AD. L. REv. 147, 153-54 (1973); Hanes, supra note 2, at 738; Leventhal, Environmental Decisionmaking and the Role of the Courts, 122 U. PA. L. REv. 509, 541 (1974).

29. See Cramton \& Boyer, supra note 10, at 415-19.

30. Haynes, supra note 26 , at 595 . This appears to be the only available recent report of systematically collected data on the duration of litigation in the states. The author would appreciate being informed by readers of empirical studies on environmental litigation's impact on court administration.

31. Id. The median duration of cases involving an appeal is 10 months and the range is 1 to 46 months. Id. at 596.

32. There are, of course, some problems in using conclusions drawn from the federal experience in discussing state legislative proposals. The size of the federal bureaucracy and the variations between state and federal procedural safeguards require that such interpolations be viewed with some care.

33. Report of the President, Acting Through the Attorney General, on the FeasiBILITY OF ESTABLISHING AN ENVIRONMENTAL COURT SYSTEM (1973).

34. Id. at III-6.

35. The REPORT discusses the impact of environmental litigation on the federal bureaucracy. Id. at III-1 to III-13. 
of the total case load in the federal courts could be classified as environmental litigation. ${ }^{36}$ However, the study failed to use a uniform definition of "environmental litigation.",37

Several studies of the volume of environmental law suits have been undertaken at the state level. Michigan continues to be the state with the most ambitious effort to count its environmental law suits. ${ }^{38}$ As of March 1976, litigation initiated under MEPA accounted for less than 119 of the over 600,000 civil actions brought in the Michigan circuit courts during the sixty-five month study period. ${ }^{39}$ Seventeen of the 119 involved appellate proceedings, ${ }^{40}$ and the Michigan Supreme Court has ruled in five MEPA cases. ${ }^{41}$ Studies of the use of the California consistency requirement ${ }^{42}$ indicate that the volume of citizen-initiated litigation-again as distinguished from the duration-is small..$^{43}$ Although the reported litigation under the California Environmental Quality $\mathrm{Act}^{44}$ has been fairly frequent, ${ }^{45}$ a preliminary analysis of the most recent of the California Judicial Council Reports ${ }^{46}$ indicates that only a small percentage of California litigation involves citizen-initiated environmental suits.

The extent to which agency action is delayed as a result of actual litigation or the threat of litigation is difficult to assess. In its recently issued comprehensive study of the National Environmental Policy Act, ${ }^{47}$ the Coun-

36. Of the 136,205 civil and criminal cases pending in federal courts (some of which may have been counted twice because they are listed as pending in both district and appellate court), 844 may be classified as environmental. Id. at III-12; environmental suits represent .3\% (270) of the 98,560 new civil suits filed between July 1, 1972 and June 30, 1973 in the district courts and $.6 \%$ of the 15,629 new filings in appellate courts. Id. at III-9.

37. See Kiechel, Environmental Court Vel Non, 3 ENVr'L L. REP. 50013 (1973). Also, the data do not indicate the number of suits initiated by citizens based on citizen environmental legislation.

38. Outside of Michigan, only a handful of suits brought under the Sax Act have been reported. DiMento, Overview 433 n.95

39. Haynes, supra note 26 , at 593 . The "less than" modifier is used because some of the cases involved administrative proceedings.

40. Id. at 592-93.

41. Id. at 593 .

42. CAL. GOV'T CODE $\S 65860$ (West Supp. 1977) requires consistency between zoning ordinances and general plans and provides for citizen suits to enforce this requirement. See note 6 supra.

43. Two questionnaire studies undertaken at the University of California, Irvine by this author and the Public Policy Research Organization indicate that the number of suits brought under the consistency provision has been small. As of the time of publication of this Article, only a handful of suits have been brought to the attention of the author.

44. Cal. Pub. Res. Code $\$ \$ 21000-21165$ (West Supp. 1977).

45. California Office of Planning and Research, California Environmental QualiTY ACT LITIGATION STUDY (1976).

46. Judicial Council of California, Judicial Council Report to the Governor and the Legislature; AnNual Report of THE ADMinistrative Office of the California CourTs (1976) (PTS. 1 \& 2).

47. 42 U.S.C. $\$ \$ 4331-4335$ (1970). 
cil on Environmental Quality concludes that "court action has contributed toward agencies taking the [environmental impact statement] process seriously in their planning and decision-making, but major unnecessary delays in federal actions have been ascribed to litigation in NEPA issues."48 Examination of the data which underlie these conclusions suggests that the number of serious delays was small. In the five and one-half years analyzed, federal agencies prepared over 6,000 impact statements. ${ }^{49}$ During that same period, only 654 suits were brought by private parties under NEPA. ${ }^{50}$ In 363 of these, the claim was made that an impact statement was required but had not been completed. ${ }^{51}$ In most of the remaining suits, the adequacy of the statement was challenged. Of the 654 suits that had been started under the Act, over half (333) had been concluded by the time of the Council's study ${ }^{52}$ Fully one-sixth of the complaints had been dismissed at the trial level $;{ }^{53}$ the ultimate disposition of the other cases often took several years. ${ }^{54}$ Four cases resulted in the issuance of permanent injunctions, but in no case was agency action enjoined beyond the time of the agency's compliance with NEPA. ${ }^{55}$

\section{Economic Costs}

Another important issue which has yet to be fully analyzed is the economic impact of state legislation giving the public greater power over environmental decisions. ${ }^{56}$ One argument lodged against citizen suits is that they provide a means for litigious individuals to harrass government agencies and promoters of unpopular land uses. ${ }^{57}$ Such abuses, the argument continues, may force industry to leave or to avoid locating in jurisdictions which provide private parties with environmental causes of action and may therefore have adverse effects on the state economy. ${ }^{58}$ The difficulties of defining the problem and designing a scientific study to determine whether

48. U.S. Council on ENVIRonmental Quality, EnVIronmental ImPact STatements: AN ANAlysis of Six Years' ExperienCe by Seventy Federal. Agencies 2 (1976). For a discussion of some of the legal problems which have arisen with respect to NEPA, see Note, Appropriate Scope of an Environmental Impact Statement: The Interrelationship of Impacts, 1976 DUKE L.J. 623.

49. U.S. CounCIL ON ENVIRONMENTAL QUALITY, supra note 48, at 32.

50. Id. at 31 .

51. Id.

52. See id. at 31-32.

53. See id.

54. Id. at 32 .

55. Id.

56. For a discussion of the impact of federal environmental legislation on a number of economic indicators, see U.S. COUNCIL ON ENVIRONMENTAL QUALITY, ENVIRONMENTAL QUALITY 1976, at $147-65$ (1976).

57. See DiMento, Overview 424. But see id, at $428-30$ (suggesting that actual experience does not bear out this expectation).

58. See Cramton, supra note 28 , at 150. 
citizen environmental suits may induce industry to leave a jurisdiction are considerable. ${ }^{59}$ However, data collected in a 1975 mail survey in states which have passed versions of the Sax $\mathrm{Act}^{60}$ provide little evidence of an exodus of industry from states with strong citizen environmental legislation. ${ }^{61}$

As to the direct costs of environmental litigation, the most comprehensive data available are from Michigan, and they remain sketchy. Plaintiffs can expect to pay two thousand dollars or more for cases pursued without a trial, and as much as ten thousand dollars for cases that go to trial. ${ }^{62}$

\section{E. Summary: A Need for Comparative Analysis}

The scarcity of empirical work done on the actual impact of the passage and use of citizen environmental legislation clearly suggests the need for further systematic studies. A nationwide analysis of the potential and actual use of the citizen environmental suit would help to clarify many issues. For the time being, the available data permit the following tentative observations:

(1) There is some evidence that government agencies may be inordinately responsive to the special interests that they are created to regulate.

(2) The courts appear to be capable of responding well to the kinds of complex issues which arise in environmental litigation.

(3) The courts do appear actually to force resolution (by adjudication or settlement) of a large percentage of the matters brought to their attention.

(4) While their volume is relatively low compared to the large number of civil cases presently heard by state and federal courts, citizen environmental suits can be time-consuming. They may require use of substantial government resources and may delay some government actions.

(5) Private litigants may be forced to expend fairly large amounts of money in pursuing environmental suits, but there is no evidence at present that the threat of citizen suits has any broader economic impact on such things as industrial location.

59. The interaction of this factor with other variables in companies' decision-making processes may confuse the issue considerably. See generally Heckert, Metropolitan Fiscal Disparities-The Business Point of View, 29 NAT'L TAX J. 336 (1976).

60. See note 4 supra.

61. DiMento, Overview 443 n. 160.

62. Sax \& Conner, Michigan's Environmental Protection Act of 1970: A Progress Report, 70 Mich. L. REV. 1003, 1051 (1972). 
Thus, citizen suits seem capable of circumventing some current problems in environmental policy-making with relatively small costs. A more difficult problem arises, however, in determining whether such suits are the best means of obtaining public participation in the policy-making process.

\section{SOME UNRESOLVED ISSUES}

While empirical research would be useful in evaluating the efficiency of citizen suit legislation, there are also many questions on which data-based responses would not be helpful. A variety of values and organizational factors must also be considered in determining when public participation is important and when citizen suits are an appropriate means of achieving that goal. Examination of these values and factors is a necessary prerequisite to the development of a conceptual structure on which future discussion and empirical research can be based.

\section{A. Why is Environmental Decision-making Special?}

To begin with, the same threshold question must be addressed in determining whether any particular area of decision-making-in this case environmental decision-making-requires special legislation to facilitate public involvement: Why should the values in that particular policy area be treated uniquely? Focusing more specifically on environmental management, this threshold inquiry concerns the extent to which environmental values should be treated differently from other societal interests. It is useful to begin the examination of this question by scrutinizing the arguments for expanding the scope of judicial review of environmental decisions and the right to seek such review.

1. Expansive Judicial Review? In arguing that decisions affecting the environment should be subject to particularly thorough judicial review, environmentalists contend that agency insensitivities to environmental concerns and values put them in a highly unfavorable position for influencing the administrative process. ${ }^{63}$

David Sive, a noted environmental lawyer, has pointed out several disadvantages which face the conservationist or environmentalist who seeks to overturn an administrative rule. The environmental plaintiff suffers all the handicaps of any small plaintiff facing a large, well-established defendant. ${ }^{64}$ $\mathrm{He}$ or she characteristically suffers from a lack of resources relative to the

63. The administrative law arena has been characterized as a "wilderness" by environmental lawyers-with a negative connotation not usually associated with use of that term by conservationists. See Sive, Some Thoughts of an Environmental Lawyer in the Wilderness of Administrative Law, 70 Colum. L. REv. 612 (1970).

64. See id. at 618. 
opponent and the fact that important information is often in the possession of the defendant administrative agency. ${ }^{65}$ These problems are often aggravated by time pressures and governmental immunities which prevent discovery of such critical information as the opinions of defendant's experts. ${ }^{66}$ Sive also argues that the environmentalist should be treated differently because challenges to environmental decisions serve an important social function. ${ }^{67}$ In addition to helping to provide public oversight for administrative actions, citizen suits can bring important information to bear on the novel and complex issues which frequently arise in environmental policy-makingissues which are often so new that administrative agencies have not yet proven their expertise to analyze them. ${ }^{68}$ Finally, Sive suggests that environmental plaintiffs should be given special advantages simply because of the "sheer importance" of the interest at issue-" "the restoration and maintenance of a livable environment." 69

Several questions are raised by this analysis which are directly relevant to the investigation of the need for environmental citizens suit legislation. The first is the extent to which environmental litigants differ objectively from other potential plaintiffs who zealously espouse values felt by them to be especially deserving of judicial protection. To the extent that provision of equal housing opportunity is not categorized as an environmental issue, it is certainly an example of such an issue. Are not plaintiffs who seek housing for all, even at the expense of environmental quality, performing tasks of some social importance? Are they not typically without means? Are not the issues they raise new ${ }^{70}$ Undoubtedly there are at least a small number of other citizen interest groups which would claim to meet each aspect of the Sive test.

A second question arises as to whether the assumptions upon which Sive bases his reform suggestions are accurate. For example, Sive emphasizes the problems which may arise from excessive pressures of time. He states that in "the typical environmental litigation . . . the aroused citizens group turns to the court as a last resort, after every political measure has failed. The suit is usually begun, figuratively speaking, in the shadow of the bulldozer . . . "71 This is an assertion which can be tested empirically.

65. Id.

66. Id. at 619. See generally NLRB v. Sears, Roebuck, 421 U.S. 132 (1975); 5 U.S.C. $\S$ 552a(b) (5) (1970).

67. Sive, supra note 63 , at 617-18.

68. Cf. id. at 625. Such issues continue to arise in environmental law. See generally Johnson, Enforcing the Federal Water Resource Servitude on Submerged and Riparian Lands, 1977 DUKE L.J. 347.

69. Sive, supra note 63 , at 615 .

70. .For an example of the novel questions which may arise in the context of equal opportunity in housing, see Village of Arlington Heights v. Metropolitan Housing Dev. Corp., 97 S. Ct. 555 (1977).

71. Sive, supra note 63 , at 618 . 
Clearly it is true for many legitimate environmental cases. ${ }^{72}$ Its correctness is less obvious, however, for the wide variety of actions which fall under the general rubric of citizen environmental suits. Challenges to environmental impact statements or construction or development plans often occur well in advance of any actual groundbreaking. In sum, it is simply not clear to what extent expanded judicial review is more necessary to protect the environment than it is to safeguard other social interests. ${ }^{73}$

2. Liberalized Standing. Similar difficulties arise in examining the rationale for granting environmentalists differential treatment in the form of liberalized standing requirements. Generally, the law of standing requires that an individual be affected, aggrieved or harmed in some tangible way as a prerequisite to seeking judicial remedies. ${ }^{74}$ The standing issue determines whether the complainant is a proper party to bring suit. To the extent that a party must be able to allege actual injury, it can be and has been argued that it will be difficult to challenge activities that are detrimental to the environment. ${ }^{75} \mathrm{~A}$ dramatic alteration in an area's ecosystem may result in serious changes in animal and plant life without any concomitant individualized injury that will prompt single individuals to undertake the expense of litigating the issue. Similar problems arise in cases where injury will be irreparable once it has occurred, but no party has any special, individualized likelihood of injury before the environmental mishap. ${ }^{76}$

These conceptual problems and the general need for liberalized standing requirements have been discussed elsewhere in great detail. ${ }^{77}$ The reader has been asked to consider standing, standing again, ${ }^{78}$ standing on the side of the environment, ${ }^{79}$ and even standing for trees and other natural objects. ${ }^{80}$

72. Consider, for example, the controversial case involving cutting of trees at the entrance to Michigan State University for road-widening purposes. Anderson v. State Highway Comm'n, No. 15609 (Cir. Ct. Ingham County, Mich., filed June 27, 1973).

73. Mr. Sive has recently noted that "political shifts" in the past few years may have diminished the force of some of his earlier observations (i.e., Sive, supra note 63). In comments prepared for the ALI-ABA-ELI-Smithsonian Institution Conference on Environmental Law, D. Sive, "Environmental Litigation, Some of its Special Aspects and Developments During 1976" (Feb. 10, 1977) (conference held in Washington, D.C.), Mr. Sive noted that the inequality of information and means between plaintiffs and defendants does not apply only to environmental controversies. Further, he noted that as a result of recently passed environmental legislation, certain industrial interests wish to expand the scope of judicial review, whereas environmentalists may wish to limit its scope. For Mr. Sive's most recently published comments on environmental litigation, see Sive, Foreword: Roles and Rules in Environmental Decision-making, 62 Iowa L. REv. 637 (1977).

74. See Davis, supra note 10, at 468. See also Baker v. Carr, 369 U.S. 186, 204 (1962).

75. See authorities cited in note 10 supra.

76. See Comment, Constitutional Challenge to the Price-Anderson Act: Ripeness and Standing Before the Holocaust, supra note 10, at 970.

77. See articles cited in note 10 supra.

78. Jaffe, Standing Again, 84 HARV. L. REv. 633 (1971).

79. Comment, Standing on the Side of the Environment, supra note 10.

80 . The article by Stone, supra note 10 , has received considerable judicial, scholarly and 
Conceptually, there is little left to be said. ${ }^{81}$ But what does need to be analyzed by those considering passage of citizen suit legislation is the extent of the need for special rules of standing for environmental plaintiffs and the potential impact of such reforms on the courts and agencies.

Regardless of the restrictiveness of the law of standing in a particular jurisdiction, important questions remain as to whether it is necessary or desirable to legislate standing for the so-called ideological plaintiff who asserts interests based solely on philosophic or religious principles ${ }^{82}$ and is currently denied standing for failure to allege "injury in fact." 83 Several issues must be considered: Are there factual situations which require rcsort to the ideological plaintiff for protection of some environmental value? Is the ideological plaintiff actually being denied standing by the courts? What are the reasons for and the implications of creating standing for the ideologue whose primary interest is the environment?

First, there is some question as to whether responsible plaintiffs are being barred from seeking judicial review of environmental decisionmaking because of the absence of any explicit legislative or judicial expansion of the standing doctrine. Two years after the Supreme Court's decision to refuse the Sierra Club standing to challenge construction of a ski resort in a national game refuge because of the a lack of any allegation of a specific individualized injury, ${ }^{84}$ District of Columbia Circuit Judge Malcolm Wilkey wrote that he was unable to find a single case in which his court had

public attention. See, e.g., Sierra Club v. Morton, 405 U.S. 727, 742-43 (1972) (Douglas, J., dissenting); Hughes, Who's Standing? Problems with Inanimate Plaintiffs, supra note 10, at 318-23.

81. Important questions remain as to the effects which such recent federal decisions as Warth v. Seldin, 422 U.S. 490 (1975), and Village of Arlington Heights v. Metropolitan Housing Dev. Corp., 97 S. Ct. 555 (1977), may have for environmental plaintiffs. See also Schlesinger v. Reservists Comm. to Stop the War, 418 U.S. 208 (1974); United States v. Richardson, 418 U.S. 166 (1974). However, the federal trend has been discussed at length. See, e.g., DiMento, Overview 417 n.16; Stewart, The Reformation of American Administrative Law, 88 HARV. L. REv. 1669, 1734-47 (1975); Comment, Constitutional Challenge to the Price-Anderson Act: Ripeness and Standing Before the Holocaust, supra note 10, at 972-85.

To the extent that a jurisdiction has adopted the liberalized standing rules of the federal courts, the discussion of the need for standing reform focuses on the desirability of permitting purely ideological plaintiffs to sue. To the extent that a state follows more traditional rules, such as the requirement of a legally protected interest or economic injury, more fundamental considerations must also be examined. A discussion of such basic concepts can be found in $\mathrm{K}$.

Davis, Administrative LAW TEXT $\$$ 22.04-.08 (3d ed. 1972).

82. See Stewart, supra note 81 , at 1734.

83. E.g., Sierra Club v. Morton, 405 U.S. 727 (1972). See note 84 infra.

84. Sierra Club v. Morton, 405 U.S. 727, 738-39 (1972):

[B]roadening the categories of injury that may be alleged in support of standing is a different matter from abandoning the requirement that the party seeking review must himself have suffered injury . . . [A] mere "interest in a problem," no matter how longstanding the interest $\ldots$ is not sufficient by itself to render the organization "adversely affected" or "aggrieved ...." 
disposed of an environmental claim on standing grounds. ${ }^{85}$ While it is unclear whether other jurisdictions have had similar experiences, it does appear that the need for special rules of standing for the benefit of ideological plaintiffs will arise relatively infrequently, "if only because a class action plaintiff's lawyer, a 'public interest' lawyer, or an organization such as the Sierra Club will normally be able to locate a plaintiff or allege injury to an organization member, who satisfies the expanding definition of legally protected material interest." 86

Where an appropriate plaintiff cannot be found, at least two questions arise as to the effect which liberalized standing may have on the administration of justice. To begin with, liberalized standing for ideological plaintiffs may affect the traditional role of the courts. As Professor Stewart has explained:

There may . . . be instances where only an ideological plaintiff, direct or surrogate, will suffice to secure representation of important affected interests. For example, there might be cases of environmental degradation in remote wilderness areas, where no individual may be able to establish material injury. Or there may be serious conflicts between the interests of those suffering immediate material injury and other, more remotely involved interests that should nonetheless be considered. Problems of [this sort are] likely to be generated by governmental policies that have important effects on the preferences and well being of future generations . . . ${ }^{87}$

But liberalization of standing laws in such situations may, he warns, "strain the logic of representation, and risk turning the courts into 'planning' agencies." 88

A related problem arises in the attempt to develop an analytic framework for determining when purely ideological plaintiffs should have standing. Justice Douglas' dissent in Sierra $C l u b^{89}$ hinted at some of the disturbing distinctions courts might be forced to make if the class allowed to represent the environment were further expanded: " $a$ fisherman, a canoeist, a zoologist or a logger . . . must be able to speak for the values which [a] river represents and which are threatened with destruction." 90 But "those

85. Wilkey, Agency Functions in Light of Environmental Problems, 26 AD. L. REv. 143, 144 (1974).

86. Stewart, supra note 81 , at 1746 . This view is exemplified in the recent decision in Village of Arlington Heights v. Metropolitan Housing Dev. Corp., 97 S.Ct. 555, 562 (1977), which reaffirms "that economic injury is "not the only kind of injury that can support a plaintiff's standing." See generally Jaffe, Ecological Goals and the Ways and Means of Achieving Them, 75 W. VA. L. REv. 1, 20-21 (1972).

87. Stewart, supra note 81 , at $1746-47$ (citations omitted)

88. Id. at 1747 (citations omitted). See also Jaffe, supra note 80, at 21-25.

89. Sierra Club v. Morton, 405 U.S. 727, 741-55 (1972).

90. Id. at 743 . 
who merely are caught up in environmental news or propaganda and flock to defend [certain] waters or areas may be treated differently." "91 Justice Douglas and several other commentators have suggested that the solution to this problem is to allow environmental issues to be tendered by the threatened natural object itself. ${ }^{92}$ Other tests could doubtless be formulated to implement the ideological plaintiff position. ${ }^{93}$ The Sax Act proposed at the federal level, for example, proposes to grant standing to parties who can "speak knowingly for the environmental values asserted in a particular case." One difficulty with such proposals is that considerable judicial resources might have to be expended to determine the capacity of the ideological plaintiff to represent particular interests or to secure some representation for interests which the surrogate chose not to represent. ${ }^{95}$

\section{B. Is the Citizen Environmental Suit Cost-Effective?}

As has been seen, there is evidence of a need for greater public involvement in environmental management and some indication that the courts can play a role in fulfilling this need. ${ }^{96}$ But further research is needed to determine whether the citizen suit is the best available vehicle. Even if it can be established that the citizen suit can serve a legitimate and useful function in environmental policy-making, an important question remains as to whether there are more cost-effective methods for accomplishing the same objectives.

1. Basic Objectives of Citizen Involvement. The basic objectives of those urging reform fall into two main categories: improving the quality of environmental decision-making and expanding the role of private citizens in managing the nation's resources. In order to assess alternative forms of citizen participation and to determine which can achieve these possibly incompatible goals most effectively, it is first necessary to define each objective more precisely.

Several conceptions of what would constitute a "qualitative improvement in environmental decision-making" can be gleaned from the literature. According to various views, the quality of environmental decision-making can be improved if:

91. Id. at 752 .

92. Id. at 741-52; see Stone, supra note 10.

93. One may ask, for example, whether standing for the ideological plaintiff is necessary to protect an identifiable interest.

94. See S. 1104, 93d Cong., 1st Sess. (1973). See also Hearings on the Environmental Protection Act of 1970 (S. 3575) Before the Subcomm. on Energy, Natural Resources, and the Environment of the Senate Comm. on Commerce, 91st Cong., 2d Sess. (1970); Hearings on the Environmental Protection Act of 1971 (S. 1032) Before the Subcomm. on the Environment of the Senate Comm. on Commerce, 92d Cong., 1st Sess. (1971).

95. See Stewart, supra note 81, at 1744 n.360, 1746; Hughes, supra note 10, at 319-22.

96. See Section I supra. 
(a) environmental values are heavily weighted in the decision process so that the environment "wins" in competition with other values; $; 7$

(b) decisions are made after comprehensive consideration of environmental factors; $; 8$

(c) a greater number of the interest groups concerned about the results of decision-making are satisfied with decisions;

(d) the actual processes of decision-making, particularly those which are unrefined, legally questionable, or highly subjective, are exposed to public scrutiny;

(e) decisions are made expeditiously;

(f) decisions are made at a level which allows for comprehensive environmental analysis.

As to the second objective, an expansion of the role of private citizens in environmental management can be effectuated in several ways:

(a) by allowing greater numbers of citizens (indeed, all who would be interested if they were aware of the environmental implications of a decision) to present their positions before a decision is made;

(b) by promoting increased citizen satisfaction after decisions are made;

(c) by involving not more, but "more informed" citizens-those who are knowledgeable about environmental matters or who "speak for" the environment;

(d) by improving lines of communication to administrative officials so that more citizen contributions are understood and processed by agency officials.

2. The Range of Alternatives. Environmentalists have recently come to rely heavily on the adversary process as a means of reaching both objectives, but a wide variety of other participatory approaches have been suggested in the literature on environmental planning. Some of these have already been employed, and all need to be recognized before an intelligent conclusion can be reached about the relative efficacy of litigation measures. In other words, in order to analyze the necessity of litigation provisions, one

97. See Catalano \& DiMento, Local Government Response to State Environmental Impact Assessment Requirements: An Explanation and a Typology, 7 ENVT'L L. 25, 33-34 (1976); Wandesforde-Smith, supra note 2, at 481 . This may be a most ambitious goal, since for some environmentalists "winning" appears to have a different meaning that it has for other interest groups. For such individuals, Professor Wandesforde-Smith has noted, "winning is an all-ornothing proposition because wilderness values are irreplaceable and priceless; not the kind of values that can be traded-off under the rubric of multiple use or according to the principles of professional forestry." Id. See notes $159-62$ infra and accompanying text.

98. The definition of "consideration" employed here was dramatically presented in Calvert Cliffs Coordinating Comm., Inc. v. AEC, 449 F.2d 1109 (D.C. Cir. 1971). 
must first assess the range of "competitive" forms of environmental decision-making which would also involve concerned citizens.

At the federal level, several agencies currently provide special procedural guarantees which enable interested citizens to participate in their rule-making processes. The Interstate Commerce Commission's Office of Rail Public Counsel and the Offices of the Consumer Advocate at the Civil Aeronautics Board and the Postal Rate Commission, for example, have all institutionalized means of offering broad representation for citizen interests in the federal bureaucracy ${ }^{99}$ Perhaps the most widely heralded reform is that provided for in the Magnuson-Moss Warranty-Federal Trade Commission Act, ${ }^{100}$ which provides for radically expanded citizen participation in certain rule-making procedures. ${ }^{101}$ Among the innovations included in the Act are mandatory public hearings in trade regulation rule-making procedures, ${ }^{102}$ opportunity for examination and cross-examination of witnesses by parties, ${ }^{103}$ opportunity to offer rebuttal testimony, ${ }^{104}$ and a requirement that trade regulation rules meet a substantial evidence test. ${ }^{105}$ In addition, the Magnuson-Moss Act creates a fund to provide for participation by those who represent interests not already included in the rule-making proceedings. ${ }^{106}$ Any party with a material interest who lacks the resources to participate effectively may be reimbursed for a wide variety of costs necessary for active involvement, including attorney fees and costs of studies. ${ }^{107}$

99. For a description and discussion of the potential benefits and limitations of these offices, see Murphy \& Hoffman, supra note 18, at 402-06.

100. 15 U.S.C.A. $\$ 57 \mathrm{a}(\mathrm{h}) 1$ (West Supp. 1976). Experience under this act is discussed in Murphy \& Hoffman, supra note 18, at 407-09.

101. See Popper, The New FTC Rulemaking Proceeding: A Guide to Effective Participation, 3 BARRISTER 57, 58 (1976).

102. 15 U.S.C.A. \$§ 57a(b), (c) (West Supp. 1976).

103. 16 C.F.R. $\$ 1.13$ (d) (5) (1976).

104. Id.

105. U.S.C.A. §§ 57a(e) (3) (A), (B) (West Supp. 1976).

106. Id. $\$ 57 \mathrm{a}(\mathrm{h}) ; 16$ C.F.R. $\$ 1.17$ (1976). But see Lenny, supra note 2, at 508: “Those who offer a different perspective but who make no new factual presentations have been denied fees."

107. 15 U.S.C.A. § 57a(h) (1) (West Supp. 1976). Under the so-called "American Rule," attorney's fees are not generally recoverable by the prevailing litigant, including the litigant acting as a private attorney general, absent specific statutory authorization. See Alyeska Pipeline Serv. Co. v. Wilderness Soc'y, 421 U.S. 240 (1975). Numerous federal statutes do provide for fee recovery in public interest litigation. See CoNGRESSIONAL RESEARCH SERVICE.

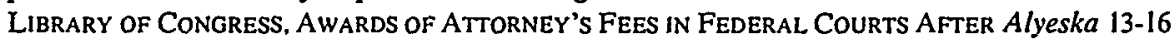
(1976), reprinted in Hearings on S. 2715 Before the Subcomm. on Administrative Practice and Procedure of the Senate Comm. on the Judiciary, 94th Cong., 2d Sess. 325-28 (1976). See also the proposed rules which would provide financial assistance to participants in Environmental Protection Agency rulemaking, adjudicatory or enforcement proceedings, 42 Fed. Reg. 1492 (1977), and the decision of the Nuclear Regulatory Commission not to initiate a program of financial assistance to indigent participants in administrative proceedings in the absence of express statutory authority to do so. Nuclear Regulatory Commission, 'Financial Assistance to 
Participation can vary from simple submission of written comments to development of the basic issues in the proceedings. ${ }^{108}$

A number of legal innovations for increasing citizen involvement in administrative activities have also been developed at the state level. The Public Council is one such mechanism which has been applied fairly widely. ${ }^{109}$ The institutionalization of consumer and environmental advocates in states' attorneys' offices is another. ${ }^{110}$ Procedural guarantees under state environmental impact assessment statutes and a judicial trend toward forcing agencies to consider environmental analyses in their decisions provide further evidence of reform in the field of state environmental law. ${ }^{111}$

Suggestions for improved decision-making have also come from outside the legal profession, stressing the need for broad participation and social experimentation. While it may be difficult to adapt certain theoretically acceptable models to the environmental decision-making arena, ${ }^{112}$ the ideas of modern social planners deserve some attention. This is particularly true because of the sharp opposition of these theorists to the case-by-case decision model which characterizes the adversary system in the administrative and judicial contexts. Called by various names-transactive planning, ${ }^{113}$ future responsive societal learning ${ }^{114}$ - these ideas generally proceed from the premise that the complexity and importance of the problems facing society are so great that it is disingenuous and even dangerous to

Participants in Commission Proceedings-Statement of Considerations Terminating Rulemaking (Nov. 12, 1976) discussed in Comment, NRC Declines to Fund Indigent Participants in Agency Proceedings, 7 ENvT'L L. REP. 10010 (1977).

108. See Popper, supra note 101, at 62 n.12.

109. See Murphy \& Hoffman, supra note 18 , at 405-07.

110. Id. Citizen advisory groups often supplement these efforts. In California, for example, a number of specialized citizens' task forces have been created to advise the state Attorney General on appropriate action to be taken with regard to a variety of matters, including environmental quality.

111. For an analysis of this trend and its implications in California, see Catalano \& DiMento, supra note 97. See generally Friends of Mammoth, 8 Cal. 3d 247, 263 n.8, 502 P.2d 1049, 1059 n.8, 104 Cal. Rptr. 761, 771 n.8 (1972) ("if the adverse consequences to the environment can be mitigated, or if feasible alternatives are available, the proposed activity, such as the issuance of a permit, should not be approved"'); Burger v. County of Mendocino, 45 Cal. App. 3d 322, 326, 119 Cal. Rptr. 568, 570 (1975) (indicating that reasons for rejection of adverse recommendations of an environmental impact review must be given). But as to the substantive impact of the California Environmental Quality Act, CAL. Gov'T CoDE \$\$ 12600-12612 (West Supp. 1977), see Breshahan v. City of Pasadena, 48 Cal. App. 3d 297, 121 Cal. Rptr. 750 (1975) (review of decision is limited to determining whether there has been an abuse of discretion). On the substantive impact of the National Environmental Policy Act and state acts modeled on NEPA, see D. Hagman, Urban Planning and Land Development Control Law \$§ 287-289 (Supp. 1975).

112. See Boyer, Alternatives to Administrative Trial-Type Hearings for Resolving Complex Scientific, Economic, and Social Issues, 71 Mich. L. REv. 111,150-64 (1972).

113. J. Friedmann, Retracking America: A Theory of Transactive Planning (Anchor Books ed. 1973).

114. D. Michael, On Learning to Plan—and Planning to Learn (1973). 
contend that any one group of experts can fashion adequate solutions. ${ }^{115}$ Diverse interests must work together to define, assess and respond to society's problems. According to this view, individual citizens must be accorded a broader role in the planning process, and changes must be made not incrementally but after "systematic examinations of the long range interactions of a technology with the rest of societal activity."116 Ad hoc approaches such as that of the adversary system are faulted because they are conservative and resistant to change and because their individualized decision-making processes are not conducive to a holistic perspective. ${ }^{117}$ Social planning theory makes strong conceptual arguments-largely unapplied-for a more decentralized decision-making process in which individuals can experiment and evaluate information about proposed technological changes, judge their implications and propose new directions. ${ }^{118}$

Other suggested reforms are legal-behavioral in nature. For such law reforms as citizen environmental suit provisions to be most effective, the advocates and utilizers of these legislative innovations must recognize and respond to the constraints under which administrative agencies operate. ${ }^{119}$ Advocates of change should identify those administrators who will be critical to organizational response: those who suggest official agency analysis of environmental bills, those who are responsible for preparing defenses to citizen suits, and those who decide whether the agency should affirmatively employ causes of action upon which the citizen suits are based. If environmentalists are to influence the shaping of policy, interaction with these critical actors must be continuous and reinforcing. Citizen suits brought without a thorough understanding of agency dynamics may result in narrow individual victories, but any real effect on policy will be

115. See J. FriedmanN, supra note 113 , at xvi-xvii.

116. Address by Donald M. Michael, "Technology Assessment in an Emerging World" at 1 (Oct. 25, 1976) (presented to the Second Int'l Cong. on Technology Assessment, at Univ. of Michigan). For a classic comparison and explication of incrementalist and comprehensive decision-making models, see Lindblom, The Science of "Muddling Through," 19 PU8. AD. REv. 79 (1959). A discussion of the need for experimentation in social planning and the problems to be encountered in such endeavors can be found in A COMMITTEe of THE SocIal SCIENCE Research Council. Social Experimentation: A Method for Planning and Evaluating Social InTERVEntion (1974). See also The Technology Assessment Act of 1972, 2 U.S.C. $\S \S$ 471-481, 42 U.S.C. \$ 1862 (Supp. IV 1974).

117. Address by Donald M. Michael, supra note 116:

[There is] a growing appreciation that societal survival requires a systems perspec-

tive, an ecological perspective, a holistic perspective. . . . A disjointed incremen-

talist approach simply won't do, though that message, while increasingly recognized

in principle, has been excruciatingly slow to be realized in practice.

Id. at 3. See also D. MiCHAEL, supra note 114 , at 4.

118. See Address by Donald M. Michael, supra note 116.

119. For discussions of the factors involved in promoting effective lawmaking and some specific suggestions for environmental reform, see H. JONES, THE EFFICACY OF LAW (1969) and J. Dimento, Managing Environmental Change: A Legal and Behavioral Perspective (1976), respectively. Also see text accompanying notes 128-31 infra. 
limited unless those interested in agency decisions involve themselves continuously in agency affairs.

From the government perspective, citizen environmental litigation may be a vehicle through which agency administrators can identify new constituencies in their decision-making fields. ${ }^{120}$ By working with newly recognized environmental interest groups, administrators can develop aggressive and comprehensive approaches to natural resource management. An adverse judgment in a citizen suit may cause an agency to restructure its operations so as to redirect attention from individual adjudication toward long-range environmental planning which enlists the aid of new and previously underrepresented citizen groups.

3. Factors in the Cost-efficiency Calculus: Areas for Research. Can any of these participatory approaches-from the pragmatic, institutionalized advocacy model of the lawyers to the idealistic "transactive" forms suggested by some planners-achieve the same objectives that might be realized through citizen-initiated litigation? Specification of the range of goals which environmentalists seek ${ }^{121}$ suggests that no one form of involvement is likely to be completely satisfactory. It appears impossible, for example, to structure citizen participation so as to achieve simultaneously both the predominance of environmental values in agency decision-making and the consideration of all the views of citizens who wish to be heard. In large part, the ranking of various strategies for achieving environmental goals through citizen participation will depend on the values and concerns of the evaluator. Regardless of the objectives sought, several areas of inquiry are relevant in judging the relative efficacy of public participation strategies.

Intrusiveness of the mode of participation. Studies of citizen participation in environmental planning indicate that decisions which are acceptable to concerned citizens can be reached using forms of involvement which are less intrusive than the citizen suit. In one such study, the analysts conclude that "when citizens participated in public hearings, a large majority of the cases resulted in the final plan representing social values and objectives, being the most technically efficient of all the alternatives, and being finally implemented; in addition, the data gathered on the plan's impact were complete and representative." 122

Citizen satisfaction. Studies by social psychologists suggest that the perception of control over a source of psychological stress can be a valuable asset in limiting the negative effects of the stress. ${ }^{123}$ Bureaucratic frustration

120. See J. DiMento, supra note 119 , at 139.

121. See Section II. B.I. supra.

122. J. GOODMAN \& E. HANSON, supra note 2 , at xxii.

123. See, e.g. Glass \& Singer, Experimental Studies of Uncontrollable and Unpredictable Noise, 4 Representative Research Soc. Psych. no.1, at 165, 175-83 (1973). 
is a form of psychological stress. The point, for purposes of this analysis, is that even if a particular form of public participation does not have a critical impact on the decision finally reached, its existence alone may contribute to greater levels of expressed satisfaction by citizen participants-one of the objectives of citizen law suits.

However, direct research on the relationship between involvement and expressed satisfaction has yielded mixed results. For example, a study of participation in the development of an Army Corps of Engineers improvement project failed to show a correlation between early and continuing participation by citizens and the amount of public support for the project. ${ }^{124}$ Another study, however, has found that participation in environmental planning efforts through membership on an advisory committee did have a positive effect on the citizens' belief that their opinions were taken into consideration by planners. ${ }^{125}$ Interestingly, a similar study found that involvement through public hearings did not have any effect. ${ }^{126}$

Potential for effecting long-term change. A third area for research derives from the literature of organizational behavior which strongly suggests that changes in bureaucrats' attitudes and behavior will be short-lived if no effort is made to influence the groups in which they work. ${ }^{127}$ Attempts to change individual attitudes must involve the actor's "role set," that is, the cluster of people who significantly influence the actor's behavior on the job, and not just the individual. ${ }^{128}$ The "role set" is the key unit for achieving organizational change: "To remove a person from his role set, tell him in a training program or executive interview that he should change his behavior, and then return him to the unchanged set burdens him with a double responsibility." 129 He must change his own behavior and at the same time effect complementary changes in the expectations and behavior of his co-workers. In order to be effective, any effort to involve the public in the decision-making process must bring public advocates together not just with individual bureaucrats but with those colleagues to whom the employee's

124. Mazmanian, Participatory Democracy in a Federal Agency, in WATER POLITICS AND Public InVolvement (H. Doerksen \& J. Pierce eds. 1976).

125. J. GOODMAN \& E. HANSON, supra note 2, at 56.

126. Id.

127. See, e.g., P. Blau, The Dynamics of Bureaucracy: A Study of Interpersonal RELATIONS IN Two GOVERnMent AGENCIES 259-62 (rev. ed. 1963). For a comprehensive treatment of the literature on approaches to promoting organizational change, see RAPPAPORT, Community PSychology: VAlues, ResearCh AND ACtion (1977).

128. R. KahN et al., Organizational Stress: Studies in Role Conflict and Ambiguity 396 (1964): "We propose that these difficulties [in creating change] are due in part to the persistent utilization of the wrong unit for achieving change; the concentration has been on the individual when it should be on the role set-focal person and role senders." A role sender is one who sends prescriptive or proscriptive messages to a person whose behavior is the focus of concern. Id. at 15 .

129. Id. at 396-97. 
positions will have to be explained and defended. The administrator named as a party defendant may be motivated to respond when change is imposed through litigation for a variety of reasons - out of general societal respect for judicial mandates, for example-but efforts at change will generally be more effective if an entire role set is involved. Just as middle-level officials cannot effect changes without lateral and vertical support, higher-level officials often encounter substantial difficulties in bringing about change where they are unable to elicit the support of their subordinates. ${ }^{130}$

This advocacy of interaction among, as opposed to litigation between, parties with interests in environmental controversies should not be interpreted as suggesting that administrative resistance to environmental goals will be immediately reduced or that solutions to problems will be readily achieved. Especially in the turbulent climate of the public sector, where administrators are subjected to myriad and often incompatible demands, bringing together potential legal adversaries with strong and sometimes highly negative perceptions of one another may initially yield undesirable results. But it is suggested that the discretionary behavior of individuals in public bureaucracies may be altered more durably through pervasive changes in the social environment in which they function than through the edicts of environmental lawsuits. As one leading commentator has described the situation,

Most administrative agencies act in a highly charged field of political forces which include the legislature, other executive bodies and officials, and a variety of more or less well-organized political, social and economic groups and interests. The internal bureaucratic organization, traditions and expectations of the agency and its personnel are also major factors in its environment. The policies adopted by the agencies, the energy and effectiveness with which they are pursued, and the agency's ultimate impact on the world may all be far more a function of these factors than the formal apparatus of administrative law. ${ }^{131}$

To the extent that this view is correct, those faced with a choice among strategies for achieving environmental objectives must balance the shortrange advantages of control gained through victories in environmental litigation against the initially less dramatic but perhaps more permanent influences of other approaches. Institutionalization of citizen environmental "watch dogs" such as the Federal Council on Environmental Quality should be considered, for example. ${ }^{132}$

Capacity to focus change efforts on points of resistance. Another difficulty with the adversary process as employed in citizen environmental

130. P. BLAU, supra note 127 , at 207-08.

131. Stewart, supra note 81 , at 25.

132. See Krier, supra note 2. 
suits is that it may fail to discriminate sufficiently among targets which environmentalists wish to influence. Litigation may preclude identification of individuals or entire bureaus within an agency which are highly sympathetic to environmental objectives. ${ }^{133}$ Components of agencies subjected to law suits are often quite diverse, and pro-environment orientations may be more prevalent than environmentalists generally believe. ${ }^{134}$ Many agency managers sincerely consider themselves to be the original environmentalists, and attacks on their efforts to promote environmental interests are surprising to them. One case in point involved the administrative impact of vigorously pursued environmental litigation brought in Michigan under MEPA. ${ }^{135}$ One state agency, the Department of Natural Resources, which had been supportive of MEPA throughout its development, was sued soon after passage of the act by plaintiffs challenging a land use decision made by the department. Attitudes toward the act were affected by the suit. As one agency official stated:

I accept [the suit] now reluctantly; I don't believe it's right. The thing that tore my guts out is for me to be fighting with another environmentalist. For someone to accuse me of not being an environmentalist! This is the only . . . thing I got going for me. I [made a decision] after sleepless nights based on what I thought was best for the environment. I get questioned all the time, 'You son of a bitch, how can you do this?' by people who pick you apart because they are ignorant of the circumstances. ${ }^{136}$

His opinion was not isolated. Many in the department who had been involved in litigation became disillusioned with MEPA. ${ }^{137}$

Since this particular department was defendant in several citizen suits, ${ }^{138}$ such attitude changes might have been expected to develop. But

133. In litigation, an agency typically will present a united front. But it is not uncommon for different components of the same agency to have diametrically opposed policy views. For one classic study detailing how one component of an agency may be highly sympathetic to environmental values while others are not, see P. SELzNICK, TVA AND THE GRASS ROOTS: A STUDY IN The Sociology of Formal Organizations 85-213 (Torchbook ed. 1966).

134. See, e.g., Wandesforde-Smith, supra note 2, at 479-80:

The majority of agency personnel are sincere and dedicated public servants, giving administrative expression to the public interest as they see it .... They do not particularly like being told they have done a less than adequate job in the past. And the kind of criticism is especially unpalatable when it comes from groups, such as the Sierra Club, that make claims on the public's attention in the name of conservation. After all, it was the men who first provided political and administrative leadership to resource management as a public function who first popularized the term conservation in the United States.

135. For a detailed report on the situation described below, see J. DiMENTO, supra note 119, at 108.

136. Id.

137. Attitudes toward the statute were investigated by means of interviews. The methodology for that study is described in id. at 14-21.

138. During MEPA's first three years this state agency had been the defendant in 14 cases under MEPA. Id. at 55-56. Haynes reports recent use of MEPA by the same department as a plaintiff. Haynes, supra note 26, at 622 . 
interviews with agency personnel indicated that negative attitudes toward citizen environmental litigation were the result of concern over the types of cases being brought ${ }^{139}$ and the treatment of agency personnel in the courtroom rather than of any negative reaction to citizen suits per se:

You know . . . honestly . . . I was raised as a scientist and you know objectively if you want to get at a problem you never tell anybody to shut up. To me the [legal] system is wrong. For somebody to tell me to shut up when I'm telling them what happened, that's completely foreign to anything I've been raised on . . . . It's really a matter of matching wits of lawyers. ${ }^{140}$

One comment by a front-office official in this agency is of particular interest in evaluating the relative benefits of the participatory and adversary methods of citizen involvement:

Hell, I'd like to sit down with them [a coalition of environmentalists] and ask, 'Now where should we go?' and deliberately plan our way. My feeling is that I'm sitting here [now] in a kind of detached way . . . . Maybe it's my job to coordinate. I don't know. I really haven't made up my mind. Perhaps I should be out there waving the flag. I feel a certain hostility [when I'm called] a rubber stamp. Again it's contrary to my nature-I'm an open guy, and I'd just as soon lay it bare with everybody . . . . But the world just isn't built that way. ${ }^{141}$

For any method of citizen involvement in public decision-making to be of continuing value, the private participant must remain cognizant of the various pressures to which the government is subject and discriminate between those individual officials who are sympathetic to reform efforts and those opposed to change.

Opportunity to speak versus opportunity to be heard. Attempts to evaluate various strategies for citizen participation must also distinguish between effective communication with administrators and the effects of presentations made before agency officials. ${ }^{142}$ This distinction between

139. See J. DiMento, supra note 119 , at 108. ("As a matter of fact . . . we're a little concerned about the court situation . . . the trends").

140. Id. at 93 .

141. Id. at $94-95$.

142. Calvert Cliffs Coordinating Comm. v. AEC, 449 F.2d 1109 (D.C. Cir. 1971), graphically illustrates the distinction at issue here. The AEC had interpreted section $102(2)(c)$ of the National Environmental Policy Act, 42 U.S.C. $\$ \$ 4321-4347$ (1970), as requiring only that its staff's "detailed statement" on the environmental impact of a proposed agency action "accompany" the proposal through the hearing process. The Commission did not require, however, that the statement even be read by the hearing board unless a party to the proceeding had raised an environmental issue. The court thought this a "ludicrous" interpretation. Congress intended that the "detailed statement" be considered by the agency in the sense of a "rigorous exploration and objective evaluation" of staff proposals and alternatives. Only this treatment would satisfy Congress' directive that the environmental impact of agency action be evaluated "to the fullest extent possible." 449 F.2d at 1117-18. 
presentation and actual communication consideration is particularly important to environmentalists:

[P]ublic interest advocates have tended to scorn resort to rulemaking proceedings on the ground that participation in such proceedings may have little impact on agency policy determinations. In notice and comment rulemaking the agency is not bound by the comments filed with it, and many such comments may be ignored or given short shrift. ${ }^{143}$

In addition, presentations to agency personnel seem to be treated in differing ways by the agency depending on the presenter's prior history of interaction and the intensity of the message presented. ${ }^{144}$ Indeed, some exchanges of views in public hearings and by written comments bear no resemblance whatsoever to communication. In litigation, on the other hand, the processing of information introduced by citizens is much more formal: interrogatories and other pretrial proceedings and the structure of the trial itself compel actual consideration of citizen analyses and presentations. It is, of course, another question whether such forced attention correlates with positive response to the information presented absent some substantive, actively enforced requirement. ${ }^{145}$

Professor Jaffe's distinction between simple and complex environmental problems may provide some guidance in evaluating the relative efficacy of citizen participation strategies:

In such situations [where the problem is a simple one such as what to do about dumping of mercury into lakes and streams], then, we must have available the direct and immediate appeal to the courts with their prestige and high potential for enforcement.

At the other end of the scale is, for example, the problem of controlling the general pollution of water systems serving densely populated industrial and commercial areas . . . . [This is a complex environmental problem requiring the development of a process of economic and acceptable standards] . . . . It should not require much argument to demonstrate that the judicial process is not well-suited to such a task. ${ }^{146}$

This comment helps to set the previous discussions in context. The varying strengths and weaknesses of judicial and administrative decision-making

143. Stewart, supra note 81 , at 1775.

144. See generally C. InSKo, Theories of AtTItUde Change 43-00, 161-00, 337 (1967). See also E. ARONSON, THE SOCIAL ANIMAL $49-87$ (1972). The range of the literature in social psychology on attitude formation and change is immense, but many of the theories cited in the Insko survey place importance on both the nature of the message and the identity of the communicator.

145. C. INSKO, supra note 144, at 223-84.

146. Jaffe, The Administrative Agency and Environmental Control, 20 Buffalo L. REv. $231,234-35$ (1970). 
processes may make various forms of citizen participation more or less appropriate in responding to particular problems.

Each of the factors that have been presented here must be considered in evaluating participatory schemes and in attempting to effect the "public interest." Before proposing a research program that will facilitate this development, however, it is necessary to examine the concept of the public interest, since it is that concept against which all discussions of cost effectiveness must ultimately be measured.

\section{In Whose Interest Is the Public Interest?}

To the extent that environmentalists can be clear about their objectives, their choices among competing means may be informed by the foregoing discussion. For the decision-maker, however, environmental considerations are only one aspect of the context in which policy choices are made. As several commentators have emphasized, environmentalism and the public interest are not uniformly equivalent. ${ }^{147}$ Environmental values are but one of several factors which must be considered in governmental decisions. Despite the ascendancy of environmentalism and the increasing number of public interest advocates (both lawyers and lay persons) who make the natural environment their primary ward, the conceptual issues raised in attempting to define and achieve the public interest remain numerous.

The nebulousness of the "public interest" presents a difficult challenge for those considering reforms in the administrative process and judicial review of that process. Some environmentalists oversimplify the challenge by using the term "public interest" quite loosely. ${ }^{148}$ The question is often raised in the legal literature (at times with a very clear indication of the author's sympathies) whether the "public interest" advocate is merely another lobbyist hoping to cloak private interests in terminology which makes his position politically dangerous to oppose. Professor Jaffe has indirectly raised this point as it relates to the environmental movement:

[T] he conservationist appears to insist that everyone should be required to take his vacation [in the wild areas of a national park] or otherwise repair to the already over-crowded places. He set his face against the multitudes who clamor for more parks and ski resorts which are accessible to those addicted to automobiles. This is an elitist concept which I can only deplore. There is plenty of room for both kinds of recreation. ${ }^{149}$

147. See, e.g., Jaffe, supra note 86, at I-16; Panel I: What is the Public Interest? Who Represents It ?, 26 AD. L. REV. 385 (1974).

148. One commentator stated flatly that "the courts need to recognize that whereas the governmental agencies are the representatives of the 'economic' interests, the conservation groups are more apt to represent the 'public interest."' Tremaine, supra note 10, at 136-37.

149. Jaffe, supra note 86 , at 15 . 
Another commentator on Canadian environmental matters has concluded that

[p]articipation from an interested and concerned public usually means little more than participation from an expanded segment of the middle class. For the most part, participation in any form will tend to favor the status quo and oppose change.

Usually the incentive behind participation in any decision is the desire to protect some vested interest. This is true for both the polluter and the environmentalist. ${ }^{150}$

It is not surprising that modern legal commentators and practitioners have failed to reach a consensus; the problem of defining the public interest has historically plagued those in the field of public administration. ${ }^{151}$ Nevertheless, the range of suggested possibilities may be condensed to three basic models. Each carries different assumptions about the responsibility of the administrator. At one extreme, there is the view that the public needs to have its interest articulated by wise public servants, administrative Philosopher Kings. The opposite extreme, based on a mechanistic view of the bureaucrat, suggests that administrators could produce decisions in the public interest if they would properly balance conflicting social interests. This model describes "wondrous engines (including the human mind) into which are poured all sorts of miscellaneous ingredients which, after a decent period of gestation, are spewed forth from time to time, each bearing a union label which reads: 'Made in the Public Interest in the U.S.A.' "'152

The difficulties inherent in conceptualizing the public interest have been so great that many administrators have sought to leave the problem to the legal community. ${ }^{153} \mathrm{~A}$ third view has arisen in response to this delegation, which holds that the public interest is best defined through the operation of the adversary system in a pluralistic society. As Dean Roger Crampton recently articulated this view, "if the process itself is fair, open and rational, . . . the outcome is the current expression of the public interest." 154 This approach has its shortcomings, and the legal profession may be able to do better. But the profession may have to live with the limited

150. Emond, supra note 2, at 783 \& n.1. See also Burch, Who Participates-A Sociological Interpretation of Natural Resource Decisions, 16 NAT. RESOURCES J. 41 (1976); Hanes, supra note 2 , at 735-39.

151. See, e.g., Schubert, "The Public Interest" in Administrative Decision-Making: Theorum, Theosophy or Theory?, 51 AM. PoL. Scl. REv. 346, 366 (1957): "[I]t is by now apparent that American writers in the field of public administration have evolved neither a unified nor a consistent theory to describe how the public interest is defined in administrative decision-making." (Emphasis in original).

152. Id. at 364.

153. See id. at 346.

154. Panel I: What is the Public Interest? Who Represents It?, supra note 147, at 386. 
conclusion that the courts and administrative agencies are somehow interacting to work toward the actualization of the public interest. It may be impossible to determine whether the public interest has been satisfactorily defined, let alone when it has been achieved.

While it may make some students of the administrative process uncomfortable to conclude that standards can be devised to facilitate working toward an outcome that cannot be clearly defined, a reasonable case can be made for this position. If that portion of the public which has previously been unrepresented in agency decision-making can be included in the decision-making process, many will agree that the decisions will be closer to the public interest than was the case prior to their inclusion. ${ }^{155}$ To conclude that the public interest may be multifaceted, that it may in fact be a blending of the numerous and perhaps incompatible positions of several interest groups, is not to conclude that developing a more just process for its realization is impossible. As two leading commentators have recently observed, "In a real sense there are many 'publics' deserving to be heard. Merely to say that a 'public representative' is already a participant should be an insufficient reason for rejecting additional participants claiming to speak for different specific 'publics.' ", 156 Perhaps this is to assert that, at this stage of the history of our extremely heterogeneous nation, "more is better" in the field of decision-making. Given the diversity among the possible strategies for improving environmental management, ${ }^{157}$ inclusion of contributions from a greater variety of perspectives may improve the quality of analysis.

Positing the desirability of hearing from as many interest groups as possible presents the problem of choosing who shall be heard when it is too costly, time-consuming or complex to hear all interested parties. There are sound and thoughtful theories of justice which can assist administrators and judges in making the difficult decisions as to what minority rights need representation in a proceeding. ${ }^{158}$ But practical difficulties arise as attempts

155. This is part of the rationale for citizen environmental litigation presented in Section II B.1. supra. See Murphy \& Hoffman, supra note 18, at 394 n.10 (comments of William D. Ruckelshaus).

156. Murphy \& Hoffman, supra note 18 , at 395 . "If the 'public interest' is pluralistic in nature, as opponents . . . have themselves frequently asserted, there is no inherent reason why more than one 'public' participant cannot be admitted to a proceeding." Id. at 413 .

157. See text accompanying notes 99-120 supra.

158. For example, the operationalization of the "pure procedural justice" described in general terms by Professor Rawls can be sought more aggressively:

In this complex of institutions, which we think of as establishing social justice in the modern state, the advantages of the better situated improve the condition of the least favored. Or when they do not, they can be adjusted to do so, for example, by setting the social minimum at the appropriate level. As these institutions presently exist they are riddled with grave injustices. But there presumably are ways of running them compatible with their basic design and intention so that the difference principle (which states that the social order is not to establish and secure the more attractive 
are made to apply the chosen theory's broad guidelines to decisions relating to the environment. Part of the controversy over standing, ${ }^{159}$ for example, derives from the absence of groups in the population legally competent to represent interests which some environmentalists believe to be essential to the survival of the world ecosystem. ${ }^{160}$ In addition, viewing the public interest as process is wholly unacceptable to those who contend that the world is nearing natural limits beyond which our ecosystem can no longer survive. ${ }^{161}$ For obvious reasons, marginal analyses which balance interests have no place in the presentations of such theorists. ${ }^{162}$

\section{The Public Interest as Process: Evaluating the Impact of Citizen Environmental Litigation}

For the great majority of policy-makers, assessment of the utility of the citizen environmental suit is influenced by the same factors present in many other areas of policy analysis. All decisions must be made with finite resources. But most policy decisions are complicated by the fact that to pursue one set of values is most often to choose against other sets which are forcefully advocated by other equally important and articulate groups within the population. The correctness of the decision reached will depend greatly on the perspective of the evaluator.

Analysis may be aided by articulating some of the trade-offs which must be considered. In evaluating alternative means of effecting greater public participation, two issues surface as focal points: how do the economic costs of the citizen suit compare with costs of citizen participation earlier in the process, and how does this cost differential compare with the difference in the degree of realization of environmental reformer's goals? ${ }^{163}$ The conclusion of this type of analysis might be that although the environ-

prospects of those better off unless doing so is to the advantage of those less fortunate) is satisfied consistent with the demands of liberty and fair equality of opportunity.

J. Rawls, A Theory of Justice 87 (1973). See also Tribe, The Supreme Court, 1972 TermForeword: Toward a Model of Roles in the Due Process of Life and Law, 87 HarV. L. REv. 1 (1973).

159. See text accompanying notes 74-95 supra. .

160. See, e.g., White, The Historical Roots of Our Ecologic Crisis, 155 SCIENCE 1203, 1204-07 (1967).

161. See Heller, Coming to Terms with Growth and the Environment, in ENERGY, Economic GROWTH AND ENVIRONMENT 3, 4 (S. Schurr ed. 1972).

162. In discussing means of achieving ecological goals, Professor Jaffe has written, "Personally, I can face with equanimity the extinction of one or another species, be it bird of bacillus of the bubonic plague. Species have died ere this. It may not be worthwhile to spend an additional $\$ 50,000,000$ to save $\$ 5,000,000$ worth of fish." Jaffe, supra note 86 , at 235 . For the environmental absolutist, such remarks represent deadly choices, not marginal compromises. While such thinking may not lead to imminent ecological disaster, the environmentalist may contend that it augurs an environmental future that not only suffers the opportunity costs of a road not taken, but forces travel on a highway leading to ultimate collapse of a life system.

163. See notes 63-95 supra and accompanying text. 
mentalists' expressed satisfaction at the end of the public hearing process is less than that expressed after judicial challenge of an administrative agency action, this cost to society-this marginal loss of satisfaction-is well worth bearing in light of the additional expense needed to achieve the marginal benefit.

Trade-offs must also be made between environmental goals and other goals which our society considers important. The ramifications of reform must be considered in terms of the entire judicial and administrative systems. To the extent that citizen environmental suits are being promoted, what types of litigation are being precluded? To the extent that environmental goals are being met by concentrating administrative energies on administrative decisions, what other activities of the regulatory agencies are being sacrificed, or pursued with less intensity?

The impact of citizen suit legislation on the administrative agencies and the courts has not been adequately specified, let alone measured. What is needed is a comprehensive program of systematic study. The closing section of this paper presents an outline of such a program.

\section{SOME RESEARCH DiRECTIONS FOR THE FUTURE}

Despite all that has been written about the potential impact of citizen environmental litigation on administrative functions, it should be clear that some very fundamental questions remain unanswered. Ignorance about the existence and potential uses of various types of citizen environmental legislation and about the institutional costs and benefits of environmental management reforms may result in misguided allocation of the environmental protection workload among the courts, administrative agencies and legislatures. Lack of information is also reflected in citizen agitation for reform when legal vehicles for change are already available and in citizens' frustration at their inability to exert more influence on admimistrative action.

To build on the empirical and conceptual work that has already been completed, two major lines of research are suggested for analysis of citizen suit legislation and its utility relative to other forms of citizen participation. One of these is legal: the results sought are analyses of the potential involvement of citizens in environmental management through the judicial system. Research is currently being conducted ${ }^{164}$ in several states on the efficacy of various forms of extra-judicial citizen involvement in environmental planning activities. What is suggested here is a more comprehensive analysis of citizen suit possibilities under various types of reforms passed or contemplated by the state legislatures. After identifying laws (other than general state admimistrative procedure codes) which provide for citizen suits

164. See note 2 supra. 
in the environmental arena, research could be guided by the following questions:

A. To what extent is each legal provision amenable to citizen use?

(1) What is the theoretical limit of its use?

(2) To what extent have legal obstacles to initiation of suit (e.g., standing, security bond requirements or absence of attorney's fees provisions) or to judicial review (e.g., doctrines of exhaustion of remedies and primary jurisdiction) been removed?

(3) Is litigation limited to controversies over resources in the public domain or are challenges to activities on private property permitted?

(4) Will the statutes be read in pari materia with other laws such as freedom of information provisions and substantive environmental and land use laws?

B. What is the legal theory on which the provision is based?

(1) Is there reliance on the public trust doctrine? ${ }^{166}$

(2) Is there reliance on causes of action such as nuisance which are traditionally available in the jurisdiction? ${ }^{167}$

(3) Is there reliance on non-self-executing constitutional provisions? ${ }^{168}$ If so, to what extent has the legistature provided remedies? 664.

165. See Note, Standing to Sue Under the Model Land Development Code, supra note 10, at

166. See DiMento, Overview 415-16; Juergensmeyer \& Wadley, The Common Lands Concept: A "Commons" Solution to a Common Environmental Problem, 14 NAT. ResourCes J. 361 (1974); Sax, The Public Trust Doctrine in Natural Resource Law: Effective Judicial Intervention, supra note 18 . This doctrine has had a variety of interpretations. In general, it states that actions by government affecting a resource that has historically been used freely by the general public should be looked upon with considerable skepticism by the courts. Read most narrowly, the doctrine's coverage extends only to land below the low-water mark on the margin of the sea and the major lakes, waters over these lands, waters within rivers or streams of any consequence, and parklands (especially if they have been donated to the public for specific purposes). But a much broader interpretation is also possible:

Public trust problems are found whenever governmental regulation comes into question, and they occur in a wide range of situations in which diffuse public interests need protection against tightly organized groups with clear and immediate goals. [Thus, the doctrine may be] equally applicable and appropriate in controversies involving air pollution, the dissemination of pesticides, the location of rights of way for utilities, and strip mining or wet land filling in private lands in a state where Id. at 556-57. governmental permits are required.

Where the doctrine does apply, a court will typically require that a governmental unit have a specific legislative mandate for any action that will change the use of a resource. Broad legislative statements about responsibilities of an agency (for example, to build roads) will not be interpreted as authority for drastic changes in the use of resources that the government holds in trust for the people (for example, filling a public pond in order to complete the road).

167. See generally Boomer v. Atlantic Cement Co., 26 N.Y. 2d 219, 257 N.E.2d 870, 309 N.Y.S.2d 312 (1970); W. PROSSER, HANDBOOK ON THE LAW OF TORTS, $\$ \S 86-91$ (4th ed. 1971 ).

168. See Johnson, supra note 68 , at $382 \mathrm{n}$. 181 and accompanying text. 
C. To what extent is each provision also amenable to use by parties other than private citizens?

(1) Are causes of action created for state agencies, cities, counties and other legal jurisdictions?

(2) Are actions available to private corporations?

(3) To the extent that these extensions have been made, how have previously available rights and remedies been expanded?

The second line of research suggested is in the sphere of social science, particularly organizational behavior. Studies of law in action are needed. To prevent some of the costly debates which arise when citizen environmental legislation is initially considered or when aniendments or repeals of reform legislation are proposed, all parties involved require more accurate information on the relative effects of the various reform proposals on the judicial and administrative processes. To fulfill this need, systematic research is required on the following questions: ${ }^{169}$

A. Judicial Administration

(1) What is the effect of citizen suit legislation on court caseloads? ${ }^{170}$

(2) Relative to the administrative agencies which have traditionally dealt with environmental issues, how well equipped is the judiciary to analyze the value-laden controversies presented by citizen environmental suits?

(3) Do the judicial procedures to which controversies are subjected expedite or impede rapid and equitable environmental decision-making?

(4) What percentage of citizen environmental suits do presiding judges classify as frivolous or harassing?

(5) Generally, what are some of the unanticipated results of citizen suit legislation?

B. Agency Administration

(1) What is the effect of citizen environmental legislation on the planning ability of administrative agency staffs?

(2) What is the impact on the regulatory effectiveness of the unit?

(3) How do citizen environmental suits affect the utility of the traditional administrative procedures of conference and conciliation as a means of solving environniental controversies?

(4) What utility do citizen suit laws have for government agencies?

169. A research proposal entitled "Citizen Environmental Legislation: Potential Use of the Citizen Suit and Perceived and Actual Institutional Impact" has been submitted to a national funding source. It covers, in three phases of analysis, several of the lines of inquiry presented in this section.

170. Some early data are presented in Section I supra. 
(a) If an agency or local government unit is authorized to be a plaintiff in an environmental suit, to what extent is this authority utilized?

(b) Are there situations where being a defendant in a citizen suit can actually help an agency to reach its goals?

(5) Are there certain types of environmental controversies which government agencies subject to environmental suits consider themselves incapable of resolving, either because of lack of expertise of lack of authority?

(6) Generally, what are some of the unanticipated effects of citizen suits on the administrative process?

Information is also needed on the economic and psychological effects of the citizen suit:

A. Economic

(1) What are the direct economic costs of citizen suits?

(a) Attorneys fees and court costs?

(b) Public costs of the time and facilities for judges and other judicial officials?

(c) Private research undertaken in preparation for suits?

(d) Costs to the government or private parties in defending citizens' suits?

(2) What are the indirect costs?

(a) Is there any significant relationship between promotion of strong economic controls and industry location decisions?

B. Psychological

(b) To what extent are industry threats backed by actual movement? ${ }^{171}$

(1) To what extent are citizens aware of the potential for their involvement in environmental decision-making under various statutory provisions?

(2) To what degree do members of the public, as opposed to public interest groups or lawyers, actually become involved in environmental lawsuits?

(3) What are citizens' motivations for initiating or intervening in a suit, and, where the citizen is a defendant, what are his or her perceptions of the plaintiffs' motivations?

(4) Do citizens actually learn of the judgments in environmental suits and scrutinize the extent to which the judgment is carried out?

(5) To what degree do citizens find satisfaction in their involve-

171. A similar problem has been experienced with local tax structures. There is an argument, for example, that high taxes are forcing industry out of the industrial Northeast to the South and Southwest, but little movement is actually reflected by the economic indicators. See Blaydon \& Gilford, Financing the Cities: An Issue Agenda, 1976 DukE L.J. 1057, 1094 n.158. 
ment in environmental lawsuits and the results of such suits as opposed to other means of participation?

\section{SUMMARY AND CONCLUSION}

A number of states have adopted various approaches in attempting to introduce public participation into administrative agency actions which affect the environment. Several have legislated substantive and procedural reforms to increase citizens' environmental rights and powers. These reforms vary from general causes of action which can be utilized to challenge a broad range of public and private actions that allegedly degrade the environment to narrowly drafted statutes which allow for judicial review of administrative agency actions in selected circumstances after the citizen has met specified procedural prerequisites.

Despite considerable legislative analysis of several types of citizen suit bills, voluminous legal comnentary and some empirical research on the impact of passage and use of the legal reforms, there remains much room for debate on the advisability of such laws. Several reasons explain the absence of definitive answers to questions about the consequences of citizen suits. These include, first, difficulties in performing empirical research for investigation of the arguments on both sides of the issue: second, conceptual difficulties in defining the true benefits and costs of proposed reforms; and third, the highly value-laden nature of the controversy. ${ }^{172}$ Suggestions have been made to meet some of these difficulties by means of legal and organizational research.

With or without additional research, legislatures and policy analysts contemplating changes in state law governing citizen suit rights must also consider the implications of proposed changes for participation in a democratic society. Increasing the power of private citizens to challenge specified administrative agency actions-or as some of the reforms have been described, providing for private attorneys general-can promote elitism and contribute to a myopic decentralization of environmental decision-making. These effects are contrary to the idea of a governnient of majority power and minority protection. Yet evaluation of a new environmental tool must be made in the context not of democracy in theory, but democracy in operation. Those who think about legislating broad citizen rights for environmental protection perhaps are not being too cynical when they point to widespread manifestations of our failure to implement democratic principles. Not the least of these manifestations is the attenuated nature of the representation which results from delegation of decision-making responsibility to administrative officials in regulatory areas which are complex, new and seemingly

172. For a particularly insightful discussion of this area, see B. ACKERMAN, et al.; THE UNCERTAIN SEARCH FOR ENVIRONMENTAL QUALTTY (1974). 
not susceptible to resolution by means of a single disciplinary perspective. Fragmentation and impersonality also characterize the administrator's resolutions of problems which are complex and multifaceted and which affect large numbers of people in a variety of ways. Although these attributes are accepted by some as inevitable concomitants of bureaucratization in a democratic society, this understanding does not justify the result. To put all this in less abstract terms, those considering policy reforms in environmental management will have to consider whether political and organizational constraints on decision-making are so great as to make democratic participation a practical impossibility.

What, for example, is the democratic response to the following situation? A municipality in a state requiring consistency between zoning ordinances and general plans has decided that its industrial and allegedly exclusionary residential zoning are consistent with its general plan that promises and promotes both equal housing opportunity and environmental quality. The residents of the municipality concur periodically by electing those who support this analysis. Is it undemocratic to deny a challenge to that finding of consistency-perhaps on environmental grounds-by a private citizen in another community? By one who lives in a community allegedly suffering from industrial pollution originating in the subject municipality? By one who lives in the municipality? By one who would live in the municipality and participate in the electoral process if housing were supplied within his or her means? Providing for citizen suits to enforce consistency in such a set of circumstances may be to promote the power of those who remember best the major premises of democratic theory.

One of the means of developing better answers to the questions which have been summarized in this article is through careful analysis of the natural experiment which now exists in this country. As was noted at the beginning of this section, states have responded in several different ways to requests for expanded citizen environmental roles. By observing the effects of these extant legislative changes on the courts, on the administrative agencies, on citizens, and ultimately, if possible, on the natural environment itself, we may be able to come up with more satisfying responses to the challenge of the environmental movement. As a by-product, we may also learn which institutional decision-making processes move us more satisfactorily toward realization of the public interest. 